\title{
Product Market Competition Shocks, Firm Performance, and Forced CEO Turnover
}

\author{
Sudipto Dasgupta \\ Chinese University of Hong Kong, Lancaster University, and CEPR \\ $\mathrm{Xi} \mathrm{Li}$ \\ Hong Kong University of Science and Technology \\ Albert Y. Wang \\ Auburn University
}

This version: October, 2017

\begin{abstract}
We examine the effect of competition shocks induced by major industry-level tariff cuts on forced CEO turnover. Both the likelihood of forced CEO turnover and its sensitivity to performance increase. These effects are stronger for firms exposed to greater predation risk and with products more similar to those of other firms. CEOs are more likely to be forced out in weak governance firms; however, in good governance firms, CEOs are offered higher incentive pay. New outside CEOs receive higher incentive pay and come from firms with lower cost structures and higher asset sales. Performance and productivity improve after forced turnover. (JEL J33, J41, J63, M4, L1, L2)
\end{abstract}

We thank David Denis (Editor) and two anonymous referees for comments that greatly improved the paper. We also thank Thomas Connelly (discussant), Vijay Yerramilli (discussant), Sun Qian (discussant), Ron Masulis, Alminas Zaldokas, a $\mathrm{n} \mathrm{d}$ Anup Agrawal and seminar participants at the Second Asian Bureau of Finance and Economic Research Conference, the Tel Aviv University 2013 Conference, the CAFS 2013 Conference, FMA 2015 Annual Meeting at Orlando, and China International Finance 2015 Conference for helpful comments. All errors are our own. Send correspondence to Sudipto Dasgupta, Department of Finance, Chinese University of Hong Kong, Shatin, New Territories, Hong Kong; telephone: (852) 3943 1913. E-mail: s.dasgupta@cuhk.edu.hk. 


\section{Introduction}

Since Adam Smith, economists have believed that competition not only is essential for efficient resource allocation but is also a fundamental driver of productivity growth. However, surprisingly little evidence exists showing that competition improves productivity or efficiency. Nickell (1996), for example, finds that empirical support for the notion that competition improves corporate performance is, at best, weak. Nickell examines a panel of U.K. manufacturing firms and finds that more competition, as measured by changes to firm-level rents, leads to more productivity growth. Subsequent work, however, has mainly focused on organizational responses to changes in competition that could be associated with greater productive efficiency. These organizational responses include greater decentralization (Bloom, Sadun, and Van Reenen 2010), technological upgrades (Bustos 2011), and higher incentive pay for top executives (Cuñat and Guadalupe 2009).

In this paper, we examine a particular type of organizational response to a change in the competitive environment, namely forced turnover of chief executive officers (CEOs). Specifically, we examine the effect of major industry-level tariff cuts on the likelihood of forced CEO turnover, and the sensitivity of such turnover to a firm's operating and stock market performance. Major tariff cuts expose domestic firms to competition from lower cost foreign producers, and improving operating efficiency is likely to become crucial for survival. It is unlikely that less efficient CEOs would be able to acquire very quickly the skills required for running a tight ship very quickly: thus, forcing these CEOs out and replacing them with those with a track record of running firms efficiently would appear to be a necessary response to foreign competition.

Consistent with these expectations, our difference-in-differences (DID) estimations reveal that both forced CEO turnover and the sensitivity of forced turnover to a firm's operating and stock market performance increase after tariff cuts. These turnover effects predominantly manifest in the first 3 years following the tariff cuts. In our baseline specification, the annual probability of a forced turnover increases more than $43 \%$ in the first 3 years after a major tariff cut. The sensitivity of forced turnover to firm's 
operating and stock market performance both increase by about $27 \%$ after tariff cut. Our main results are reported in the context of linear probability models incorporating firm fixed effects. However, they are robust to probit estimation using industry fixed effects and a variety of additional robustness checks.

More intense competition from lower cost foreign producers is likely to alter the product market behavior of domestic firms, which in turn affect the survival prospects of the weakest or the least efficient. We document two product-market-related, competitor-driven strategic effects that come into play more forcefully following tariff cuts and find that the likelihood of forced CEO turnovers increases particularly for firms vulnerable to such effects. First, consistent with the idea that firms with inefficient CEOs are likely to become predation targets (Telser 1966; Benoit 1984; Bolton and Scharfstein 1990), CEO turnover increases more after tariff cuts in industries with higher threat of predation by conservatively financed rivals. Second, firms with more elastic demand curves are likely to lose more market share if their rivals become more efficient and lower costs (Raith 2003). Thus, such firms in turn have a greater incentive to lower costs by firing inefficient CEOs. We find consistent evidence.

Inefficient CEOs are likely to be in charge primarily in poorly governed firms - indeed, in our sample, firms with poor governance are much more likely to have lower productivity and higher likelihood of default within their respective industries. When we split our sample on the basis of various measures of governance quality, we find that the effect of tariff cuts on forced CEO turnover is only present for the subsample of poor governance firms. Our results thus suggest that while poor governance allows inefficient CEOs to hold on to their jobs in normal times, this is no longer sustainable when competition from lower cost foreign rivals intensifies. Since exit is costly, boards of such firms-out of reputational concerns, fiduciary responsibility, or heightened shareholder pressure - only become proactive when firm survival is threatened. Our finding that more intense competition has the greatest impact in poorly governed firms complements the finding of Giroud and Mueller (2010, 2011), who find that when managers get more entrenched, firm value and performance are adversely affected only in uncompetitive industries.

CEO firing decisions are costly processes and it is pertinent to ask why alternative mechanisms of dealing with the threat of competition, such as providing CEOs with more incentive pay, might not be used 
instead. Indeed, Cuñat and Guadalupe (2009) find that more import penetration is associated with higher pay-performance sensitivity for top executives, and the pay gap widens between the CEO and other top executives. We find similar results for our sample. However, when we split our sample on the basis of our governance measures, we find these effects only for firms with good governance. This is consistent with the view that inefficient CEOs, and in particular those that lack the skills for cutting costs, cannot simply be incentivized to learn the art. Such CEOs are more likely to be in poorly governed firms, and forcing these CEOs out and bringing in more capable ones is the only way to achieve cost efficiency. In contrast, in well governed firms, inefficient CEOs are likely to have already been weeded out. Therefore, the ones at the helm at a given point of time are likely to respond to pay incentives by increasing cost-reducing effort (Raith 2003).

We examine outside successions in which the previous employer of the new CEO is a publicly traded firm. Our arguments imply that to cope with competition from lower-cost rivals, boards will bring in CEOs with a track record of running their firms efficiently. We find that relative to the control sample of firms not exposed to tariff cuts, outsider CEOs of firms exposed to tariff cuts tend to come from firms that have lower cost of goods sold; have lower selling, general, and administrative expenses; have higher sales of plant, property, and equipment; and are more likely to have engaged in an asset sale. We also find that such CEOs receive higher pay, more long-term incentive pay, and more performance-sensitive pay, consistent with the notion that the new CEOs are deemed to have skill sets most amenable to incentive provision, like in the good governance firms.

Finally, we examine whether forced CEO turnovers are associated with subsequent performance improvements. We perform two types of exercises. First, we match firms that experience forced turnover with other firms in the same 3-digit SIC industry that do not experience CEO turnover. We then compare the change in $t$-period average profit margin, return on equity, $q$, sales growth and total factor productivity before and after the tariff cut year for the treated and the control groups, where $t$ is 1,2 , or 3 years. Treated firms experience significantly higher performance improvement than the control group. Second, for each firm experiencing a forced CEO turnover following a major tariff cut, we randomly pick another firm in 
the same industry outside the 3-year window around the tariff cut event that also experiences a forced CEO turnover. Each group of firms is then matched to a control group based on industry, size, and the propensity of a forced CEO turnover. We then compare the performance improvements of the two groups relative to their controls (triple difference). We find that performance improvements (relative to controls) are significantly higher following forced CEO turnovers that occur after major tariff cuts than those that occur at other times, suggesting that more intense competition imposes harsher penalties on firms that do not take corrective action.

We contribute to the literature in several ways. First, we show that forced CEO turnovers increase in response to more intense competition. Prior studies on the relationship between competition and CEO turnover find limited and mixed empirical evidence. DeFond and Park (1999) find a significantly negative correlation between CEO turnover and the Herfindahl-Hirschman index (HHI) based on publicly listed Compustat firms. However, Ali, Klasa, and Yeung (2009) show that the negative correlation disappears when HHI is instead based on Census data that contains both publicly listed and private firms. An issue with this line of research is that measures such as the HHI could be related to the rate of CEO turnover even when there is no causal relationship between the two. For example, technology shocks or other types of shocks to an industry could lead to both more CEO turnover and exit of weaker firms, leading to more industry concentration. Moreover, cross-industry comparisons of CEO turnover could be comparing steadystate situations when hiring and firing decisions have already taken place. In contrast, our analysis focuses on firms' CEO retention decisions in response to competitive shocks. These shocks are exogenous to the individual firm or manager, but nonetheless affect firing and hiring decisions, because the benefits from replacing a manager are reshaped by the shocks. Second, we contribute to the literature on the connection between internal and external governance by showing that product market competition can improve internal governance via the forced departure of inefficient CEOs. Third, and finally, we show that CEO dismissals are in fact associated with performance improvements: competition improves efficiency by weeding out inefficient managers.

\section{Hypotheses}


In this section, we develop our hypotheses on how CEO retention decisions of firms are likely to be affected when the industry experiences a significant tariff cut. To do so, we draw on the theoretical literature on competition and incentives (Schmidt 1997; Raith 2003) and CEO dismissals (Hirshleifer and Thakor 1994, 1998; Hermalin and Weisbach 1998, 2003). To the best of our knowledge, no existing theory links competition, incentives, and retention decisions in a unifying framework.

\subsection{Tariff cuts and forced CEO turnover}

Tariffs are typically imposed to protect the market shares of domestic producers from more cost efficient foreign producers. When an industry experiences a significant reduction in that protection due to exogenous lowering of tariff rates (e.g., as part of multilateral trade agreements), domestic producers are suddenly exposed to competition from their lower-cost foreign counterparts. As a result, prices and profit margins in the industry are likely to decrease.

To survive, domestic producers need to respond to this competitive threat. There are a number of possible strategies that could increase the survival prospects of a domestic firm - e.g., introducing new products, increasing advertising to differentiate their products from those of their rivals, diversifying into other lines of business (possibly through M\&A). However, firms may have to step up their R\&D activities before they can launch new products; increasing advertising or entering into new lines of business also requires significant expenditure. For firms experiencing decrease in profitability, raising the required financing from internal as well as external sources could be difficult. As a result, perhaps the most effective strategic response is to become more competitive by running a tighter ship, for example, by cutting costs and selling off loss making divisions.

The role of the CEO is likely to be crucial for a firm's attempt to become more cost-efficient. Some CEOs are empire builders and are unwilling or unable to take the hard decisions that are required to improve efficiency, for example, selling off loss making divisions, laying off workers, or simply leading by example and championing a less profligate corporate culture. Moreover, cost-cutting is not a skill or a trait that a CEO can acquire very quickly. CEOs with management styles that breed inefficiency may not be able to reverse their styles very quickly. Thus, not only does the threat of bankruptcy not discipline them, it may 
also be difficult to incentivize them to improve efficiency by altering compensation contracts. Therefore, when a firm has not been run efficiently by the incumbent CEO, and improving efficiency is the key to survival, firing that $\mathrm{CEO}$ and bringing in someone who has a track record of cutting costs or selling assets is likely to be an effective strategic response.

1.1.1 Tariff cuts and performance sensitivity to forced CEO turnover. A large literature does find that CEOs are more likely to be fired after poor performance. Theory suggests that CEO firings occur because shareholders or the board of directors update their prior beliefs about the CEO's ability after observing performance. If performance is sufficiently poor, they find it worthwhile to incur the costs associated with firing the incumbent and engaging in a costly search for a new CEO of higher ability (Hirshleifer and Thakor 1994, 1998; Hermalin and Weisbach 1998, 2003). Not enough is known, however, about the extent to which firing decisions in response to poor performance are occurring in this optimal manner, as implied by theory. For example, is the board or are shareholders misattributing poor performance to the CEO when it is due to reasons outside the CEO's control? ${ }^{1}$ Is the board trying to protect its reputation at the expense of the CEO's? When the origin of the adverse shock is not known, it is difficult to conclude that CEO firing decisions in response to poor performance are optimal decisions.

An advantage of studying the impact of more intense foreign competition on forced CEO turnover decisions is that we are able to observe (1) whether firms respond in the way suggested by theory; (2) whether the ones most likely to benefit from forced CEO departures respond more; and (3) whether performance does improve for the firms that respond, relative to those that do not.

Increase in the likelihood of forced CEO turnover and its sensitivity to performance after tariff cuts are consistent with optimal firing decisions. In the post-tariff cut environment, with the average cost of production in the industry coming down due to competition from lower cost foreign rivals, only higher ability CEOs (in the pool of domestic firms in the industry experiencing tariff cuts) will be able to compete effectively. Put differently, the ability threshold for CEO retention will increase, leading to more forced

\footnotetext{
${ }^{1}$ Kaplan and Minton (2012) and Jenter and Kanaan (2015) find evidence consistent with misattribution.
} 
CEO turnover. Further, the sensitivity of turnover to performance will also increase. If shareholders and the board are learning about CEO ability from firm performance, the likelihood that the CEO retains his job will be lower after tariff cuts for the same underperformance (relative to the average performance of all domestic firms). ${ }^{2}$

These considerations lead to the following hypothesis:

Hypothesis 1: The likelihood of forced CEO turnover, and the sensitivity of forced CEO turnover to firm performance, increases for firms in an industry experiencing a tariff cut. ${ }^{3}$

1.2 Product market characteristics, competitor reactions, and forced CEO turnover

Product market characteristics, and how a firm's competitors respond to a competitive shock such as a tariff cut, are likely to play an important role for CEO retention decisions. First, since the weaker firms in the industry could be brought to the brink of exit following a major tariff cut, inefficient firms that do not respond immediately by replacing their CEOs are vulnerable to predatory strategies from rival firms. Lower cost rivals, especially that are conservatively financed, may be willing to sacrifice short-term profits by lowering prices to levels that inefficient firms cannot match and therefore must exit the industry. Thus, one would expect that the likelihood of CEO turnover after tariff cuts is higher in industries in which the risk of predation is greater.

Second, the firm's incentive to reduce costs is likely to be stronger if the demand curve for its products is more elastic, that is, when the firm's products are more similar to those of other firms. This follows because if a firm is relatively more inefficient relative to its competitors, it will lose more market share as the competitors charge lower prices. If competitors respond to tariff cuts by improving efficiency, the cost imposed on the firm of harboring a CEO who is unable to do the same increases.

\footnotetext{
${ }^{2}$ For example, if prior to the tariff cuts, the lowest $5 \%$ in the ability pool would have been unable to survive, after the tariff cut, that percentage could increase to $10 \%$. So now a firm in a given (low) percentile rank of the performance distribution would have a lower probability of survival. This is likely to correspond to a lower retention likelihood of the CEO for the same underperformance relative to the median or the mean.

${ }^{3}$ Note that, to the extent that current performance is not a sufficient statistic for CEO ability and the boards have other "soft information" about ability or past observations on performance, we would expect to see both the probability of forced CEO turnover and the turnover performance sensitivity to increase.
} 
These considerations lead to the following hypotheses:

Hypothesis 2: The effect of tariff cuts on forced CEO turnover is stronger (a) in industries in which the most conservatively financed firms and those with larger cash holdings account for a larger fraction of the industry sales and (b) for firms that have products that are more similar to those of other firms.

Part (a) of hypothesis 2 is premised on the notion that predation is most likely when a few large firms have low leverage and are able to sustain temporary reduction of profits or draw on a "war chest." When weaker firms leave the industry, and the gains accrue to existing firms roughly in proportion to their market share, the largest firms have the most incentive to predate. ${ }^{4}$

2.3 Exit, incentives, and governance

The literature on the effect of increased competition on managerial effort incentives (operating via incentive contracts offered by shareholders to managers) does not necessarily deliver the result that more competition induces more effort. Closest to our setting is Schmidt (1997), who shows that when managers have costs of job separation, the increased threat of liquidation associated with more intense competition reduces the cost to shareholders of providing incentives for cost-reducing effort. Similar to Schmidt (1997), we view the effect of tariff cuts as creating a tournament in which the lowest performers (e.g., the bottom $10 \%$ ) among the domestic producers must exit. However, there are two key differences. First, we do not regard the problem of inefficiency as a pure "provision of effort" problem as in a standard moral hazard setting. Some CEOs may have very low ability, or effort productivity, when it comes to improving cost efficiency. These CEOs may nonetheless survive without competition shocks because governance is poor. Second, we argue that that exit imposes costs on the shareholders or the board, and when the likelihood of exit for poor performers increases following tariff cuts, inefficient CEOs may have to be fired.

Product market competition and corporate governance have often been considered as alternative mechanisms of disciplining management. Giroud and Mueller (2011) find that better governed firms (as

\footnotetext{
4 Telser (1963), Benoit (1984), and Bolton and Scharfstein (1990) provide theoretical foundations for predatory strategies by “deep pocket" rivals. Chevalier (1995) finds evidence of predation following leveraged buyouts (LBOs) in local supermarkets when rivals have low leverage and are concentrated.
} 
measured by the GIM index) earn higher returns than poorly governed firms only in noncompetitive industries, as measured by the HHI. They attribute this result to the possibility that there is greater managerial slack in noncompetitive industries when governance quality is low, but not in more competitive industries, as competition eliminates managerial slack. Consistent with this argument, they find that in noncompetitive industries, poor governance firms make more value destroying investment expenditures and also have lower productivity. Giroud and Mueller (2010) find that firms' operating performance deteriorates after the passage of state-level business combination laws (which made managers more immune from the discipline of hostile takeover threats) only in noncompetitive industries.

Giroud and Mueller $(2010,2011)$ thus find that governance improvements matter more for firm performance or firm value when the discipline of competition is absent. The "dual" to this result is the proposition that an exogenous increase in the threat of competition matters more when governance is weak. This makes sense in our context because firms with good governance should already be run efficiently as a result of better external governance (e.g., takeover threat) or better internal governance (designing better compensation contracts to incentivize managers or firing inefficient managers). In contrast, poorly governed firms may have managers that entrench themselves via empire building (Morck, Schleifer, and Vishny 1989) and pay little attention to improving productivity or keeping down costs. Thus, when competition breaks out and lower-cost foreign firms gain access to the market, the poorly governed firms are the ones that need to respond to the competitive threat by firing inefficient managers.

It is possible that the discipline of competition itself eliminates organizational slack and it is not really necessary to fire the CEO. However, CEOs who have never run a tight ship may not find it easy to acquire the necessary skills quickly, and more importantly, the board or shareholders may not trust such a CEO to successfully implement changes. In other words, while more intense competition might align the incentives of the CEO and shareholders, continuing with the same CEO may be perceived as too risky. Thus, one expects forced turnover of CEOs to increase, especially in poorly governed firms.

Who takes the decisions in poorly governed firms, where managers are supposedly entrenched, to fire the $\mathrm{CEO}$ ? We argue that there are costs of firing CEOs, and as long as the costs outweigh the benefits 
for the decision maker, CEOs will retain their jobs. For shareholders, these costs are not only the search costs to the firm of finding replacements, but perhaps more importantly, the costs associated with activism and putting pressure on the board. For directors, especially in poorly governed firms, these costs are likely to stem from loyalty to the CEO, who may have appointed them. Similar to Schmidt (1997), we argue that liquidation imposes a different set of costs on both shareholders and directors. The former lose the value of their investment in the firm, and the latter suffer reputational damages, which could involve shareholder lawsuits, losing out on other potential directorial positions, or, if they hold executive positions for their companies, even spillover effects for their companies. The benefits from firing the CEO are the avoidance of these costs. When tariff-cut-induced foreign competition increases the likelihood of liquidation, the benefits may dominate the costs associated with firing the CEO. Thus, the shareholders or the boards become more proactive in poorly governed firms, where inefficient managers are more likely to be found.

These considerations lead to the following hypothesis:

Hypothesis 3: (a) Firms with poor governance are more likely to be of lower productivity and have higher default probability than firms with good governance. (b) The likelihood of forced CEO turnover, and the sensitivity of that turnover to performance, will increase more in poorly governed firms than in well governed firms after tariff cuts. ${ }^{5}$

In contrast to poorly governed firms, well governed firms are likely to have CEOs in place who are running the firm efficiently, as implied by the findings of Giroud and Mueller (2011). Thus, CEO firings are unlikely to generate significant benefits for these firms when they face new competition from foreign producers. However, these firms may still need to incentivize their CEOs to respond effectively to the threat from foreign competition. For example, CEOs may need more high-powered incentives to enter new markets or new lines of business which are not in their comfort zone. They may have to be given long-term incentive pay rather than short-term cash compensation to steal market share from weaker firms via

\footnotetext{
${ }^{5}$ Relatedly, we also expect that firms with low productivity and high default probability are more likely to be poor governance firms and that the likelihood of forced CEO turnover and the performance sensitivity of turnover increases after tariff cuts for such firms compared to high productivity and low default probability firms. Although we do not present these hypotheses formally, we provide supporting results in the Online Appendix.
} 
predatory tactics (which involve sacrificing profits today for higher future profits). Indeed, Cuñat and Guadalupe (2009) find that more import penetration is associated with higher pay-performance sensitivity for top executives, and with a widening of the pay gap between the CEO and other top executives. We expect that one should see similar effects following tariff cuts, and the effects should be mostly confined to firms with good governance.

Hypothesis 4: CEO total pay, long-term pay, pay-performance sensitivity (pay alignment), and the pay gap between CEOs and other non-CEO executives will increase after tariff cuts. These effects should be stronger in firms with good governance than in firms with poor governance.

\subsection{Post-turnover performance and tariff cuts}

We argued above that the main motivation for forcing out inefficient CEOs subsequent to tariff cuts is to improve efficiency. It is possible, however, that boards are firing CEOs to protect their own reputations: if things go wrong later, they would not be blamed for lack of proactivity. In fact, such "scapegoating" is more likely to occur when it is relatively unlikely that performance can be turned around. In contrast, if the $\mathrm{CEO}$ is fired to improve efficiency, one should expect the performance improvement to show up in the subsequent performance of the firm. The relevant benchmark here is the performance of peer firms in the same industry that are exposed to the same competition shock, have the same ex ante likelihood of firing the CEO, but do not (e.g., because the CEO is too entrenched).

Since performance of most firms in the industry is expected to drop after tariff cuts, the relevant metric is the change in performance compared to that before the tariff cut, for treated firms versus matched control firms (i.e., the "difference-in-differences" of performance). Thus, we expect the following.

Hypothesis 5: (a) Firms that fire their CEOs after tariff cuts show more performance improvement relative to prior performance than matched firms in the same industry that do not fire their CEOs.

Firing CEOs and improving efficiency should be associated with more significant relative improvement in performance when the competitive threat from lower-cost foreign producers has intensified. Therefore, we should expect that the performance improvements relative to matched industry 
peers should be stronger for firms that fire their CEOs subsequent to tariff cuts than for firms that fire CEOs in normal times.

Hypothesis 5: (b) Improved performance by firms that fire CEOs following tariff cuts (relative to matched firms in the same industry that do not fire CEOs) should be greater when CEOs are fired immediately after tariff cuts than at other times.

If managerial entrenchment is an important reason why many firms do not fire their CEOs after tariff cuts, we expect these firms would invite predation from conservatively financed larger firms in the industry. Consequently, firms that do not fire CEOs after tariff cuts, on average, should experience more performance deterioration relative to those that fire CEOs when the possibility of predation is high. In other words, the "triple difference" in performance should be positive. A similar argument applies to firms that face elastic demand curves, as they are likely to lose more market share as their rivals' lower prices.

Hypothesis 5: (c) The effect outlined in Hypothesis 5a should be stronger (1) in industries in which the most conservatively financed firms account for a larger fraction of the industry sales and (2) for firms that have products that are more similar to those of other firms.

\section{Sample and Data}

To measure reductions in import tariffs, we use product-level U.S. import data compiled by Feenstra (1996), Feenstra, Romalis, and Schott (2002), and Schott (2010). These data span the period 19742005 and cover 146 manufacturing industries (200-399 SIC range). Following Valta (2012), for each 3digit (SIC) industry-year, we compute the ad valorem tariff rate as the duties collected by the U.S. Customs Service in the 3-digit industry divided by the free-on-board value of imports to that industry. To identify sizable variation in barriers to trade, we follow Frésard (2010) to characterize tariff reductions in terms of the deviations in the yearly changes in tariffs from their median level. Accordingly, a major tariff cut occurs in a specific industry-year when a negative change in yearly tariff rate is 3 times larger than its median negative change in the industry over our sample period. Moreover, to make sure that large tariff reductions truly reflect nontransitory changes in the competitive environment, we exclude tariff cuts that are followed 
by equivalently large increases in tariffs within the subsequent 3 years. We also drop all industries for which we do not have tariff data.

We obtain CEO turnover data from the Standard and Poor's (S\&P) ExecuComp database, which covers about 1,500 firms each year that are in the S\&P 500, S\&P mid-cap 400, and S\&P small-cap 600 indices. Our sample period covers the years 1993-2005, representing the intersection of our ExecuComp sample and the tariff data. We include all firm-years that have an identifiable CEO (using CEOANN). We obtain stock return data from the Center for Research in Security Prices (CRSP) and firm characteristics from the Compustat Industrial and Segment files. Governance data are from RiskMetrics (formerly called Investor Responsibility Research Center (IRRC)). After merging the tariff data with the CEO data from ExecuComp, we are left with 93 unique 3-digit SIC industries. There are 61 industries experiencing at least one tariff cut during our sample period, with the remaining 32 industries experiencing none.

While we mainly focus on the change of import tariff, the change of export tariff could be triggered at the same time as part of the bilateral (or multilateral) agreements between the United States and other countries. Thus, it is not obvious that the demand curve for exporting firms shifts left following the import tariff reduction as the export market can improve simultaneously. Further, exporting firms in industries not subject to tariff cuts could be benefiting from tariff reductions by trading partners of the United States as part of bilateral and multilateral trade agreements, and should be removed from the control group. To address such concerns, we exclude all exporting firms from our sample. ${ }^{6}$

\section{Empirical Methodology and Baseline Results}

We now explain our empirical methodology and discuss our baseline results. We first discuss the merits of our choice of industry-level tariff cuts as a quasi-natural experiment aimed at avoiding potential issues of endogeneity.

\subsection{Tariff cuts as a quasi-natural experiment}

\footnotetext{
${ }^{6}$ An exporting firm is defined as having positive export sales recorded in Compustat. On average, export firms account for $27.3 \%$ of the sample per year. In Table A5, we show that there are no significant results for exporting firms.
} 
In trying to understand how competition affects CEO turnover, the main challenge we face concerns finding measures of competition at the industry level that are exogenous to CEO turnover decisions at the individual firm level. Traditional measures of industry concentration such as the HHI are subject to endogeneity: the distribution of sales or output among firms in an industry could well be the outcome of firm strategies rather than be a determinant of such strategies. ${ }^{7}$ In view of this, several recent papers have used industry-level major tariff cuts as quasi-natural experiments to study how (change in) competition affects corporate policies (e.g., Feenstra 1996; Feenstra, Romalis, and Schott 2002; Frésard 2010; Valta 2012; Frésard and Valta 2012, 2015). These papers contain excellent discussions as to why tariff cuts are a valid quasi-natural experiment in the context of the issues they address. While our dependent variable of interest is different, some of the same arguments apply.

In our context, perhaps the most important possibility to rule out is that industry-level tariff cuts are in response to factors that would also have caused more frequent CEO departures in the absence of these cuts. Such a possibility would be plausible if the industries which experience tariff cuts happened to be declining industries. Politicians_-perhaps influenced by export lobby groups seeking access to foreign markets as part of reciprocal trade agreements - decided to open up to foreign competition industries that would be difficult to salvage. To see if this is the case, and whether our results could be driven by such cases, we do two things. First, we directly test whether the major tariff cuts that occur in our sample period could be predicted by prior industry conditions or trends, such as growth of sales and earnings, market conditions, and so on. We find no supporting evidence. ${ }^{8}$ Second, we only consider for our empirical tests tariff cuts that were a part of multilateral trade agreements and were across-the-board, and thus not narrowly

\footnotetext{
${ }^{7}$ For example, if some dominant firms in an industry are able to drive out new entrants, the CEOs of these firms may enjoy long tenures. The industry will appear to be concentrated by traditional measures such as the HHI; however, both the HHI and low CEO turnover are outcomes of successful firm strategies and are not causally related to each other.

${ }^{8}$ This result, in the spirit of similar tests by Frésard and Valta (2015), is reported in the Online Appendix.
} 
directed at particular industries. Our results hold for these tariff cuts, which in fact account for a majority of the tariff cuts in our sample period. ${ }^{9}$

There are good reasons to believe that these multilateral tariff cuts beginning in the early 1990s were the result of broad consensus in the United States in favor of trade expansion (see Destler 2005). There is no reason to believe, however, that lobby groups in declining industries would lobby to reduce tariff protection: in fact, theory and evidence suggests the opposite. Thus, most plausibly, the groups that benefited were exporters, and importers of intermediate goods. We exclude exporters and exclusively focus on firms that produce only for the domestic market in our empirical tests.

Figure 1 confirms that tariff cuts affect our sample firms as expected. Figure 1A plots industry tariff rates around tariff cut events at the 3-digit industry level for the affected industries (those with major tariff cuts at the event year) and the control group of unaffected industries (those without major tariff cut from 3 years before to 3 years after the event year). The average tariff cut in the affected industries is about 1.5 percentage points. Figure 1B shows the associated increase in import penetration in the affected industries. As expected, import penetration increases in the industries experiencing tariff cuts rather dramatically, but there is no such effect in the unaffected industries. Figure $1 \mathrm{C}$ shows the median return on equity (ROE) of the affected and unaffected industries. ROE falls for the affected firms immediately after the tariff cut, and keeps declining. Finally, Figures 1D-1F show the behavior of aggregate industry investment, sales and cash holdings of the domestic firms, all of which decline around the tariff cuts. However, there are no such trends for the control group.

\subsection{Forced CEO turnover}

Following Parrino, Sias, and Starks (2003), a CEO turnover is classified as forced if the Wall Street Journal reports that the CEO is fired, is pushed from the position, or departs for unspecified policy differences. For the remaining cases, the departure is classified as forced if the departing CEO is under the

\footnotetext{
${ }^{9}$ Unlike some of the above-mentioned studies, our sample period begins in 1993, the first year that we are able to readily obtain information on CEO turnover. Subsequent to 1992, a majority of the tariff cuts were the result of multilateral trade agreements.
} 
age of 60 and (1) the Wall Street Journal announcement of the succession does not report the reason for the departure as involving death, poor health, or the acceptance of another position (elsewhere or within the firm) or (2) the announcement reports that the CEO is retiring but does not announce the retirement at least 6 months prior to the succession. The circumstances surrounding the departures of the second group are further investigated by searching the business and trade press using Factiva and LexisNexis for relevant articles to reduce the likelihood that a turnover is incorrectly classified. We also collect information on the departing CEOs career path and use an additional filter: when a CEO under the age of 60 cannot be found in a new position in any of the databases, we consider the departure as forced.

Panel A in Table 1 presents some statistics for CEO turnover rates in our sample. We define turnover in a given fiscal year $t$ to occur if the CEO in year $t$ is no longer the CEO by the following year, $t+1$. We exclude all nonstandard turnovers, that is, turnovers due to an acquisition, bankruptcy, or delisting. Panel A of Table 1 presents the level of CEO turnover by year and by type. The turnover rate for standard turnovers is $14.13 \%$. The sum of standard and non-standard turnover rate in our sample (unreported) is $16.69 \%$ over the entire sample period, implying average CEO tenure of 6 years. Kaplan and Minton (2012) report a $15.6 \%$ turnover rate using S\&P 500 firms for a slightly different sample period. The average rate of forced turnovers is $4.64 \%$; that is, 1 in every 22 CEOs is fired in an average year. It has been suggested (Kaplan and Minton 2012; Jenter and Lewellen 2014) that the actual rate of forced turnovers is possibly higher as many forced turnovers are misclassified as voluntary turnovers. Therefore, we also report turnover statistics for an expanded definition in which a departure that results in a new position for the CEO at a smaller firm and with lower pay is also classified as forced. The last two columns in panel A report the statistics corresponding to this definition. This alternative definition results in an average forced turnover rate of $8.51 \%$.

\subsection{Main empirical specifications and baseline results}

Taking advantage of the different timing of major tariff cuts across industries, as well as industries without any cuts during our sample period, we adopt a difference-in-differences approach to examine (1) 
the relation between competition and forced CEO turnover and (2) how the sensitivity of forced CEO turnover to firm performance is affected after the tariff cuts.

To estimate firms' responses to tariff rate reduction, we construct an "event episode" for each firmyear observation in the treatment group. We consider a firm is treated if the industry (based on the 3-digit SIC code) it operates experiences a tariff rate reduction that is larger than 3 times the median tariff rate reduction in the same industry over the period 1974-2005. Each event episode for a treatment firm consists of six consecutive firm-year observations (excluding the event year $t$ of the tariff cut) from 3 years before (year $t-3$ ) to 3 years after (year $t+3$ ). We use 3 years as the post-event window because we are interested in the response of firms in the industry to the shock, which is likely to occur soon after the incidence of the shock. ${ }^{10}$ Further, any change in CEO turnover in the long run is likely to be influenced by many other confounding factors. For each "event episode", we analogously construct a control group using six consecutive firm-year observations for those firms that do not experience a tariff cut before event year $t .^{11}$ If an untreated firm later gets treated by a different event, all post-event firm-year observations for that firm are dropped from the control group.

We then "stack" the data across all "event episodes" (i.e., across all tariff cut reductions) and estimate the average treatment effect. Specifically, we estimate the following linear probability model (LPM):

$$
y_{i j t}=\delta \times C U T_{P O S T 3}+\beta_{0} \times P M_{i, t-1}+\gamma_{0}^{\prime} \times X_{i, t-1}+\gamma_{t}+\mu_{i}+\varepsilon_{i, j, t} .
$$

The dependent variable is a binary variable that takes the value of 1 if there is a forced CEO turnover event for a firm in a particular year and 0 otherwise. $i, j$, and $t$ represent the firm, industry, and year, respectively. CUT_POST3 is an indicator variable that is equal to 1 for the first 3 years after the firm's industry has experienced a tariff rate reduction larger than 3 times the median tariff rate reduction in the same industry, and 0 otherwise. $\gamma_{t}$ and $\mu_{i}$ represent, respectively, year and firm fixed effects. The coefficient of interest is

\footnotetext{
${ }^{10}$ For example, a firm may be able to find a CEO with the right set of skills for the new environment quickly, so no further adjustment is expected in the long run in response to the shock.

${ }^{11}$ We go back 5 years before our turnover sample to exclude firms previously treated from the control group. We require that a firm exists when the industry experiences a tariff cut in order to be considered as treated.
} 
the effect of the competition shock, $\delta$, which is expected to be significantly positive (Hypothesis 1 ). Standard errors are robust and clustered at the 3-digit SIC industry level to account for industry-wide correlations among firms.

Our performance measures $\left(P M_{t-1}\right)$ are the firm's operating performance (return on assets, $\left.R O A\right)$ and stock performance (stock returns, RET) in the previous year. ${ }^{12}$ Both measures are "industry-adjusted" by subtracting the mean contemporaneous 3-digit SIC industry performance. We include other control variables described in panel B of Table 1, which comprise several firms, CEO, board, and governance characteristics and an industry characteristic.

In addition to the industry-adjusted performance variables, we include the following control variables: Salechg, annual sales growth from year $t-1$ to year $t$; Assets, the natural logarithm of total assets; $Q$, the sum of market value of equity and market value of debt divided by replacement value; and Volatility, the standard deviation of firm's monthly stock return from year $t-5$ to year $t-1$. In addition, to the extent that CEO turnover could be affected by certain CEO, governance or board characteristics, or the competitive structure in the industry, we include related control variables. We include two CEO-specific variables: a dummy variable if the CEO is older than 65 (Age_dummy) and the length of tenure (Tenure). We include two governance characteristics: the percentage of shares owned by Institutional Investors (Institutional ownership) and the G-index in Gomper, Isshi, and Metrick (2003) (G-index). We also include two board characteristics: the size of the Board (Board size) and the percentage of independent directors (Board Independence). We include $H H I$ to control for industry concentration. Panel B in Table 1 presents summary statistics for tariff rates and the control variables in our baseline regressions. Over the sample period, the tariff rate is $4.887 \%$, but it can be as large as $17.84 \%$ for some sectors and 0 for others. The substantial variation of tariff rate across industries can also be inferred from the large standard deviation of 5.817\%.

Panel A in Table 2 reports the estimation results for Equation (1). Column 1 shows our model estimates controlling for industry-adjusted performance and other control variables commonly used in the

\footnotetext{
${ }^{12}$ In tests not reported here, we also consider the prior 3-year average of the relevant performance variable. All our results are quantitatively similar.
} 
literature (Jenter and Kanaan 2015; Kaplan and Minton 2012), and year and firm fixed effects, to make sure our results are in line with prior literature. The two measures of firm performance, ROA and $R E T$, are both significant and negatively related to the forced CEO turnover likelihood, which confirms that forced CEO turnover often occurs after poor performance. In Column 2, we add the dummy variable for tariff rate cut, CUT_POST3, but include only firm and year fixed effects. The coefficient on CUT_POST3 is significantly positive $(p<.01)$. In Column 3, we add back the other control variables from Column 1. Finally, in Column 4, since forced turnover outcomes could be related to board characteristics, we include board size and board independence as additional controls. While our sample size is reduced by about 30\%,CUT_POST3 remains significant at the $5 \%$ level. $^{13}$

In terms of economic magnitude, holding other variables at the mean, forced CEO turnover likelihood increases by 2.0 (1.2) percentage points in Column 3 (4) when an industry experiences a substantial tariff rate cut. This represents a 43\% (26\%) increase over the unconditional likelihood of forced turnover of $4.6 \%$. Put differently, while roughly 1 out of 22 CEOs are fired in a given year, this rate increases to 1 out of 15 (17) each year in the first 3 years immediately after a tariff cut.

Next, we examine whether tariff cuts affect the sensitivity of forced turnover to firm performance. To do so, following Ovtchinnikov (2010), we augment the specification in Equation (1) by adding an interaction term between the tariff cut dummy and all control variables. Hence, Equation (1) changes to

$$
\begin{aligned}
y_{i j t}=\delta & \times \text { CUT_POST } 3+\beta \times{\text { CUT_POST } 3 \times P M_{t-1}} \\
& +\beta_{0} \times P M_{t-1}+\gamma^{\prime} \text { CUT_POST } 3 \times X_{i, t-1}+\gamma_{0}^{\prime} \times X_{i, t-1}+\mu_{i}+\gamma_{t}+\varepsilon_{i, j, t} .
\end{aligned}
$$

We focus on the interactions of CUT_POST3 with the two performance measures $\left(P M_{t-1}\right)$. If forced CEO turnover is more sensitive to past performance after the tariff cut, we would expect the coefficients (betas) on the interaction terms CUT_POST3 $\times P M_{t-1}$ to be negative and significant (Hypothesis 1).

\footnotetext{
${ }^{13}$ Data on board size and board independence were collected from RiskMetrics, where they are only available after 1996.
} 
The results in Columns 5 and 6 confirm that the sensitivity of forced CEO turnover to firm performance increases after the tariff cut as both interactions are negative and significant. In terms of economic magnitude, the sensitivity of forced turnover to firm's operating and stock market performance increases by $26.9 \%$ and $27.4 \%$, respectively, after a tariff cut. In addition, the coefficient of the CUT_POST3 variable remains positive and significant.

\subsection{Robustness checks}

In this section, we discuss several robustness checks for our baseline results reported in Table 2. Since board information is only available after 1996, we use the specifications in Columns 3 and 5 of Table 2 as our main specification throughout.

First, we conduct a placebo test by randomly assigning a tariff-cut year to each industry, and repeat the analysis in Columns 3 and 5 of Table 2. The results are reported in the last two columns of Table 2. Neither CUT_POST3 nor its interactions with the performance variables are significant in these regressions.

Second, we explore the dynamics of the effect of major tariff cuts on forced CEO turnover. Figure 2 shows point estimates from a linear probability regression of CEO forced turnover on tariff cut using firm-year panel data. The specification is the same as that reported in Table 2, Column 3, except that the effect of tariff cut is allowed to vary by year for each year from 2 years before the tariff cut to 3 years after. Also plotted are 95\% confidence intervals (dash lines), adjusted for clustering at the 3-digit standard industrial classification (SIC) codes. The figure shows that the coefficient of the tariff cut dummy is insignificant prior to the tariff cut but becomes significantly positive in the first year following the cut and increases to 0.035 in the third year after the cut. Figure 3 presents a more comprehensive picture and is generated similarly, except that the effect of tariff cut is allowed to vary by year for each year from 6 years before the tariff cut to 9 years after. ${ }^{14}$ The effect of a major tariff cut is no longer significant at the $5 \%$ level

\footnotetext{
${ }^{14}$ Figure 3 is generated based on an estimation method using panel data similar to that in Bertrand and Mullainathan (2003). A firm is considered as treated in year $t$ if it has experienced a major tariff cut, and control firms are those that have not yet experienced a major tariff cut, including those that are treated at a later point in time.
} 
after year 3, which is consistent with our expectation that most of the adjustments to the shock would occur fairly quickly (here, within the first 3 years of the shock).

Third, we address concern about pre-trends by conducting a matched sample analysis. Following Frésard and Valta (2015), we construct our sample as follows. Treated firms are those in industries that experience a significant import tariff reduction. In the year before the tariff cut, these firms are matched by the logarithm of total assets, Tobin's q, cash flow to total assets, cash holding to total assets and sales growth to previously untreated firms in a different industry. We keep treated and matched firms from 3 years before to 3 years after the tariff cut (excluding the event year) and drop matched firms if they get treated. The results (reported in Table A2 in the appendix) are very similar to those in Table 2.

Fourth, we address the possibility that tariff cuts could be endogenous, and therefore the relationship between tariff cuts on CEO turnover need not be causal, by focusing on multilateral trade agreements. The multi-country-industry dimension of such agreements limits the vulnerability of government officials to political pressures of interested parties, and for that reason, these reductions can be viewed as relatively more exogenous than reductions resulting from bilateral agreements. We make two attempts to separate out the multilateral agreements. First, the General Agreement on Tariffs and Trade (GATT) initiated a multilateral trade negotiation, with 125 countries signing the agreement in 1993. Shortly thereafter, the World Trade Organization (WTO) was established as the successor to the GATT. Accordingly, we separate the sample into pre- and post-WTO periods, with the latter period being more likely to involve the multilateral tariff agreements. The subperiod analysis is presented in the first two columns of Table A3 in the appendix. The magnitude of the effect of tariff reduction on CEO turnover and turnover-performance sensitivity is in fact larger in the post-WTO period than the pre-WTO period. As our sample period starts in 1992, we have a limited number of years for the pre-WTO period. To achieve a more balanced subperiod analysis, while maintaining the exogenous nature of multilateral agreement, we calculate the number of industries that are affected by major tariff reduction in each year. We then consider the years that have the number of affected industries above the sample mean as the period in which the tariff agreement is less subject to political pressure or special interest (we call it the high clustering group). 
The results are presented in the last two columns of Table A3 in the appendix. The results in panels A and B suggest that tariff reductions affect forced CEO turnover and turnover sensitivity to firm performance more significantly when a greater number of industries are affected.

Fifth, we examine whether the effect on CEO turnover depends on the strength of the treatment. Our definition of major tariff cuts already excludes cuts that are not at least 3 times as large as the median tariff cut in the industry. Within this group, we further define smaller (larger) tariff cuts as those for which the absolute change of tariff rate below (above) the mean of all absolute changes of tariff rate, which is 1.52\%. In Columns 1 and 2 of Table A4, we estimate our baseline linear probability model separately for these two groups. Only the larger cuts have any significant effect on the likelihood of forced CEO turnover and the performance sensitivity of the turnover.

Sixth, we examine whether the effect of tariff cuts on forced CEO turnover is stronger in less competitive industries. This is expected since the discipline of competition should leave less room for inefficiency and managerial slack in more competitive industries (Giroud and Mueller 2010, 2011). Results reported in Columns 3 and 4 of Table A4, where we split the sample based on the industry HHI being above or below the sample mean in the previous year, confirms that the effect of tariff cuts on forced CEO turnover are stronger for the less competitive industries.

Seventh, we show that the extent to which tariff reduction necessitate a CEO turnover depends on firms' exposure to the affected product markets. Firms with all their products in a single industry may be affected most if that industry faces a dramatic change in competition from foreign firms. Hence, we collect data from Compustat Business Segment files and separate the single segment firms from multiple segment firms. Similarly, we separate firms based on their degree of concentration in segment sales. We consider firms with their HHI of segment sales in the previous year above the mean of all firms in the same industry as less diversified group. We present the subgroup analysis in the first four columns of Table A5. We find that tariff reduction leads to higher likelihood of CEO turnover and higher turnover-performance sensitivity in single segment firms or less diversified firms, but these effects are weaker or non-existent for multisegment and more diversified firms. In Column 5 of Table A5, we examine the effects of major tariff cuts 
on exporting firms. We find tariff cuts to have no effects on the forced CEO turnover likelihood or performance sensitivity of forced CEO turnover of exporting firms. This is consistent with the idea that exporting firms also benefit from the tariff changes through their exporting business, and therefore face less pressure to remove inefficient or entrenched CEOs.

Eighth, we estimate our baseline model for the expanded definition of forced turnover which, in addition to the filters used in our analysis to identify forced turnovers, considers turnovers that result in lower pay for the $\mathrm{CEO}$ at a smaller firm as forced. As reported in the last column in panel A of Table 1, the frequency of forced turnover according to this classification is $8.5 \%$; that is, in a given year, 1 in every 12 CEOs is fired. Our regression estimates indicate that the effect of a major tariff cut is to increase the frequency of forced CEO turnover according to this expanded definition by 3 percentage points. This translates to 1 in every 9 CEOs being fired in a given year immediately after a tariff cut. These results are reported in the Online Appendix Table OA1.

Ninth, and finally, we show that our results are robust to alternative estimation methodology. The LPM could be problematic if a high proportion of the predicted values lie outside the unit interval. This does not appear to be a problem in our context because around $82 \%$ of the predicted values for the estimations in the first six columns of Table 2 lie within 0 and 1 . Nonetheless, we replicate our tests for a probit model incorporating industry fixed effects. The results (reported in Table A6 in the appendix) are qualitatively unchanged: the marginal effect of a tariff cut ranges from $1.3 \%$ to $2 \%$. All results in the paper are robust to this estimation method and the major results are available in the Online Appendix (Tables OA7-OA10).

\section{The Effect of Product Market Characteristics and Competitor Reactions on Forced CEO Turnover}

For domestic firms, exposure to foreign competition is likely to invoke strategic reactions from rival domestic firms. As discussed in Section 1.2, predatory strategies by rivals are one response. Predation is especially likely in industries in which there are large rivals with significant cash holdings that can be used as a "war chest" to finance competitive strategies (see Fresard 2010) or with low debt ratios so that they can sustain operating losses for some periods. Our measure of industries that have conservatively 
financed (financially flexible) major rivals is the percentage of industry sales accounted for by rivals that have debt ratios (cash holdings) that are below (above) the 25th (75th) percentile for the industry. As seen in Columns 1 to 4 of Table 3, consistent with Hypothesis 2a, the effect of CUT_POST3 on forced CEO turnover and the performance sensitivity of turnover are stronger (and with two exceptions, only significant) for the industries in which predation is more likely.

A second way in which rival strategies influence a firm's CEO retention decisions is the impact their cost-reducing efforts are likely to have on the firm. If the firm's demand curve is very elastic, then not only is the punishment more severe when rivals are able to lower costs and charge lower prices, their incentives to do so are also greater because of the potential "market stealing" effect. We use Hoberg and Phillips' (2011) firm-level total product similarity index and group firms into "high" and "low" similarity subgroups based on whether the firm's similarity index is above or below its 3-digit SIC industry mean in the previous year. As indicated by Hypothesis $2 b$, we expect the effect of tariff cuts on forced CEO turnover to be higher when similarity is higher, and this is what we find in Columns 5 and 6 in Table 3.

In Section 7, we consider performance changes following forced CEO turnover. We show that the performance gains from firing CEOs (relative to not firing them) following tariff cuts are higher when firms are more exposed to the rival strategies discussed above. In other words, rival strategies hurt firms more for not firing inefficient CEOs when they are more exposed to such strategies.

\section{Corporate Governance and Forced CEO Turnover}

In this section, we explore the role corporate governance plays in the forced CEO turnover decisions subsequent to major tariff cuts. If firms with weaker shareholder rights or weaker boards are doing a worse job of replacing inefficient management (Jenter and Lewellen 2014) in normal times, then an increase in the intensity of product market competition makes it more imperative for such firms to replace the CEO.

We use four proxies for governance. Our first measure is the G-index in Gomper, Isshi, and Metrick (2003). Firms with high values of the G-index are characterized by weak shareholder (or strong managerial power), creating slack and inefficiency. Since entrenched CEOs may be under less pressure to perform under normal times, our second measure is the entrenchment index (or E-index) in Bebchuk, Cohen, and 
Ferrell (2009). A less independent board may be captured by CEOs and thus more likely to tolerate underperforming or less competent CEOs during normal times. We calculate the proportion of outsider directors on the board as a proxy for board independence. Finally, institutional investors are better monitors than individual shareholders (Denis, Denis, and Sarin 1997; Harford, Jenter, and Li 2011). Thus, boards of firms that have lower institutional ownership are likely to be under pressure to dismiss less capable CEOs (only) when the firm is under extreme stress. Therefore, the percentage of shares held by institutional investors is our fourth measure of governance.

To test our hypothesis, we partition our sample firms into two groups based on the value of the governance proxy as of the previous year. We define poor (good) governance firms as those with a percentage of independent directors (institutional ownership) below (above) the industry mean or G-index or E-index above (below) the industry mean. We then estimate regressions similar to those in Table 2 for each of the two groups for each governance variable.

Hypothesis 3a stipulates that weaker governance should be associated with a higher percentage of firms being closer to default and having low productivity than under stronger governance. These are the firms that are most vulnerable to competition from more efficient foreign producers, and thus the ones that have the most need to replace inefficient CEOs. Panel A of Table 4 shows that, for each governance classification, firms that are below industry mean in total factor productivity $(T F P)$ and firms with below industry mean z-score are in the majority when governance quality is below the industry mean. Exactly the opposite is the case when governance quality is above the industry mean. Panel B shows that when firms are partitioned based on TFP or z-score, low governance quality firms are in the majority when $T F P$ or zscore are below industry mean, and the opposite is the case when TFP or z-score are above industry mean. ${ }^{15}$

Table 5 presents the tests for Hypothesis 3b. Panel A presents the results on the frequency of forced CEO turnover. The coefficients on CUT_POST3 are significantly positive for the weak governance subsamples, but not significant (with one exception) for the strong governance subsamples. The coefficients

\footnotetext{
${ }^{15}$ In Table OA2 in the Online Appendix, we show that the effect of tariff cuts on forced CEO turnover is only present for low TFP and low z-score firms.
} 
for the two subsamples are also significantly different for each proxy (with one exception, although the economic magnitude is still 3 times larger for the poor governance subsample). The marginal effects are of the order of 3 percentage points, which are highly economically significant in relation to the overall frequency of forced turnover of $4.6 \%$ for the overall sample. In panel B of Table 5, we examine the sensitivity of forced CEO turnover to firm performance. After the industry tariff rate is reduced, forced CEO turnover is more strongly and negatively associated with firm performance for firms with poor governance, while firms with strong governance show smaller and in many cases insignificant change in the sensitivity of forced CEO turnover to firm performance.

Next, we examine whether board turnover rates or board composition changes occur after major tariff cuts. To ensure that director turnover or board composition change is not caused by a forced CEO turnover, we exclude all firm year observations that fall into the 3-year period immediately after any forced CEO turnover. In panel A of Table 6, the dependent variable in the first column is a dummy variable that equals 1 if the total number of departing and incoming directors exceeds $50 \%$ of the board size in year $t$, and 0 otherwise. ${ }^{16,17}$ CUT_POST3 is insignificant in this regression, suggesting that there is no abnormal board turnover following tariff cuts. In Column 2, the dependent variable is a dummy variable that equals 1 if the status of board changed from classified to unclassified or conversely in year $t$, and 0 otherwise. Again, CUT_POST3 has an insignificant effect on this variable. Finally, in Column 3, the dependent variable is a dummy variable that equals 1 if there is any change of the percentage of independent directors on the board in year $t$, and 0 otherwise. Once again, a major tariff cut has no effect on this variable. Collectively, these results are suggesting that there are no major changes in board structure or composition in response to tariff cuts.

\footnotetext{
16 Thus, if a single board member is replaced in a board comprising seven members, the ratio is $(1+1) / 7<1 / 2$. This, therefore, is not counted as a board turnover event. However, a situation in which 2 members leave and are replaced is considered a turnover event.

${ }^{17}$ As a robustness check, we also use $75 \%$ as a threshold for director turnover dummy, the coefficient on CUT_POST3 remains insignificant.
} 
These results are in line with findings in Bebchuk (2003) and Cai, Garner, and Walkling (2009) that almost all director elections are uncontested and directors typically receive more than $90 \%$ support in voting. ${ }^{18}$ The latter paper, however, finds that fewer votes for independent directors are associated with subsequent CEO turnover. Moreover, proxy advisors such as ISS and Glass-Lewis suggest that withholding votes by shareholders can be an effective disciplining mechanism. In related research, Del Guercio, Seery, and Woidtke (2008) find that "vote-no" campaigns during director elections targeted at specific directors can have disciplining effects in terms of increased CEO turnover and performance improvements. Cai, Garner, and Walking (2009) also find that directors receiving a negative ISS recommendation get significantly lower levels of support. Given these findings, even without abnormal board turnover, shareholder dissatisfaction or the potential for such dissatisfaction can cause boards to fire inefficient CEOs when firm survival is threatened following major tariff cuts.

We find some evidence that subjecting board members to shareholder evaluation makes forced turnovers more likely following tariff cuts. Since more directors are up for reelection in unclassified boards, we expect that shareholder voting would have a more effective role for such boards. We find consistent results. In panel B of Table 6, we interact CUT_POST3 with a dummy variable, Unclassified, which takes the value of 1 if the board is not a classified board in the previous year, and 0 otherwise. Tariff cuts have a more significant effect on forced CEO turnover in poorly governed firms only when the board is unclassified.

\section{The Carrot or the Stick?}

Next, we turn to incentive provision via compensation contracts as an alternative way of motivating managers. We argued in Section 1.3 that since cost-cutting is a skill that profligate managers who get entrenched are unlikely to acquire quickly, we do not expect incentive provisions to be effective and adopted widely in poorly governed firms following tariff cuts. Forcing these CEOs out and replacing them

\footnotetext{
${ }^{18}$ During our sample period, a majority of firms only allowed plurality voting, in which a director can win by a single vote in uncontested elections. Moreover, boards largely nominate new directors, and shareholder proxy access is severely limited.
} 
with CEOs who are better at improving efficiency is likely to be more useful. In contrast, in better governed firms, inefficient managers are likely to have already been weeded out when the tariff cuts happen, and the productivity of cost-reducing effort is likely to be higher for the CEOs in charge. Thus, for such firms, incentive provision via compensation contracts is likely to increase following tariff cuts. Such contracts could also be used to motivate other types of actions that could be optimal responses to the competitive threat for firms that are already operating efficiently, as argued in Section 1.3. Hypothesis 4 captures some of the implications that emerge from these considerations.

In panel $\mathrm{A}$ of Table 7, to test Hypothesis 4, we replicate some of the analysis in Cuñat and Guadalupe (2009) for our sample. ${ }^{19}$ While we find no significant effect of tariff cuts on CEO's total compensation following tariff cuts, we do find that short-term compensation (salary and bonus) is lower, pay-performance sensitivity (incentive alignment) is higher, and the pay gap between the CEO and other highest paid executives is higher. ${ }^{20}$ In panel $\mathrm{B}$, we contrast the effect of tariff cuts on incentive alignment in good and bad governance firms. For all our governance measures, we find that incentive alignment is higher after tariff cuts for the good governance firms, but there are no significant effects (with one exception) for the poor governance firms. These results are consistent with Hypothesis $4 .^{21}$

\section{Characteristics of New CEOs}

A key element of our arguments has been the notion that CEOs with specific skillsets are required for a firm to survive competition from lower cost foreign producers. If the current CEO does not possess these skills, replacing that CEO and bringing in someone with a track record of managing firms with low cost structures or selling off assets may be the best way to survive.

\footnotetext{
${ }^{19}$ We exclude cases in which a forced CEO turnover occurs in the 3 years after the tariff cut.

${ }^{20}$ Following Kale, Reis, and Venkatasawaren (2009) and Kini and Williams (2011), pay gap is defined as the difference between the log of the CEO's total pay and the log of the median total pay of the other top five highest paid executives in the company.

${ }^{21}$ In Section 1.1, we considered the question of why tariff-cut-induced competition shocks are different from other types of shocks. In the Online Appendix, following Harford (2005), we examine (1) the impact of major industry shocks on the likelihood of forced CEO turnover and (2) CEO compensation. For industry shocks in general, we do not find any evidence that CEOs are more likely to be fired. We do find that CEO total pay and long-term pay increase.
} 
In Table 8, we examine the characteristics of the new outside CEOs who replace CEOs who are forced out. The first three columns consider, respectively, the cost of goods sold (COGS), selling, general, and administrative expenses (XSGA), and sale of plant, property, and equipment, in the old firm. These three dependent variables are scaled by net plant, property, and equipment, and averaged over the last 3 years. The fourth column considers as a dependent variable the probability of asset sales in the old firm, which is a dummy variable that takes the value of 1 if the old firm sold a subsidiary in any of the last 3 years. For the first four columns, since we examine characteristics of the firms these new CEOs come from, we can only consider outside successions. The regressions are run on the sample of forced turnovers (and outside successions) only. CUT is a dummy variable that takes a value of 1 if the industry of the new firm experienced a major tariff cut in any of the last 3 years, and 0 otherwise. We find that compared to normal times, after tariff cuts, the new CEOs are recruited from firms that have lower cost structures and are more engaged in asset sales, characteristics likely to be useful in dealing with new competition.

In the last two columns of the table, the dependent variables are, respectively, the total pay and incentive alignment of the new CEOs in the new firm. In these regressions, we consider both internal and external hires. The results show that, following forced turnovers that occur immediately after major tariff cuts, the new CEOs receive higher pay, and pay packages providing more incentive alignment, than in other periods, after controlling for their previous pay. This is similar to the response of good governance firms that are more likely to incentivize their CEOs rather than fire them subsequent to tariff cuts. These effects, however, are stronger for external hires.

Finally, in Table 9, we test whether the new managers would be more strongly incentivized relative to departing managers following tariff cuts, compared to a control sample of forced turnovers that occur outside of the 3 years following the tariff cut. Table 9 compares the change in various dimensions of the pay of new and departing CEOs who are hired and fired, respectively, in the same firm following tariff cuts with those of CEOs who are hired and fired at other times. Consistent with our expectation, the differencein-differences analysis shows that total compensation, long-term compensation, pay gap, and incentive alignment are all higher for the new CEOs who are hired following the tariff cuts. 


\section{Firm Performance Changes after Forced CEO Turnover}

If forced turnover subsequent to tariff cuts represents an organizational response to more intense competition aimed at improving efficiency and the odds of survival, then we expect to see performance improvements in firms that fire CEOs after major tariff cuts. In this section, we examine this issue.

To do so, we first use a difference-in-differences approach and test Hypothesis 5a. We define "treated" firms as those that experience a forced CEO turnover in any of following 3 years in industries that experienced tariff cuts. Next, we construct a sample of "matched" firms that are similar to treated firms except for the occurrence of CEO turnover. For each treated firm, with replacement, we choose its "nearest neighbor" in the same year of turnover based on firm size, same industry (3-digit SIC code), and the implied probability of CEO turnover. ${ }^{22}$ In other words, matched firms are those that share similar predicted odds of CEO departure as treated firms, but the board did not respond by firing the CEO. ${ }^{23}$

We then compare performance changes 1,2 , and 3 years after the CEO turnover year relative to 1 , 2, and 3 years, respectively, before the turnover year for the treated group and the control group of matched firms. The performance measures we examine are profit margin, return on equity $(R O E)$, sales change, total factor productivity (TFP), and Tobin's q $(q)$. The results, presented in Table 10, show that except for $q$, for all other performance measures, the average performance change in the treated group is significantly higher than that of the control group when measured from 2 years before to 2 years after and from 3 years before to 3 years after the tariff cut event. Additionally, for profit margin and TFP, the change is significantly higher for the treated group when measured from 1 year before to 1 year after the event. These results imply that firms do weed out inefficient managers as part of an organizational response to intense competition.

\footnotetext{
${ }^{22}$ The implied probability of forced turnover is calculated based on the regression in Column 1, Table 2.

${ }^{23}$ The matching procedure minimizes the possibility that cross-sectional differences across firms and industries affect performance differences. In addition, since the probability of a CEO being fired is highly sensitive to firm performance, the matching procedure implicitly matches firms on prior performance. This minimizes the possibility of incorrect inferences based on mean reversion; for example, if performance is mean-reverting and firms with poor performance are more likely to fire CEOs, subsequent performance improvement in the latter group could be due to mean reversion. To make certain that mean reversion does not drive these results, we replicate the analysis reported here for a matching procedure that explicitly incorporates lagged return on assets and lagged stock returns. The results, available in the Online Appendix table OA3, are very similar. We thank an anonymous referee for pointing out the possibility of our results being driven by mean reversion.
} 
In Table 11, we go further and test for performance differences following tariff cuts for firms that fire CEOs and matched firms that do not, for forced CEO turnovers that occur in the 3 years following tariff cuts, and those that occur at normal times (Hypothesis 5b). Specifically, for each forced turnover that occurs after a tariff cut, we find from the same industry another firm that experiences a forced CEO turnover outside the 3 years before and after the tariff cut. We match both sets of firms to control firms based on size, industry and propensity for forced turnover, and compute, for each of our performance measures, the difference in the 3-year average of that measure after the forced turnover and before the forced turnover. The results reveal that performance improvements are significantly higher for tariff-affected firms when they fire CEOs relative to control firms than for firms that fire CEOs at other times, consistent with Hypothesis $5 b$.

Finally, in Table 12, we provide evidence that when strategic responses by rival firms are more likely, firms that fire their CEOs following tariff cuts outperform more significantly than matched control firms that do not fire their CEOs (Hypothesis 5c). We first compute the difference in 3-year average performance change around tariff cuts for firms that fire CEOs and matched control firms that do not. We then compare this difference-in-differences statistic for groups that are more susceptible to predation (above sample average based on rival's Deep pocket, Financial flexibility, and Similarity) to the groups that are less susceptible to predation (below sample average). The results, reported in Table 12, largely support Hypothesis 5c. The triple difference is positive for 14 out of 15 cases and significantly positive at least at the $10 \%$ level in 11 cases.

\section{Conclusions}

In this paper, we examine how managerial retention decisions respond to greater competition intensity: whether competition weeds out inefficient management and how firm governance matters. To do so, we focus on industry-level major tariff cuts for U.S. producers, which represent exogenous shocks to the competitive environment in these industries. Such an approach has major advantages over industrylevel concentration measures such as the HHI, because the latter only can make cross-industry comparisons 
in steady state equilibrium, whereas forced CEO turnovers by their very nature are disequilibrium phenomenon and represent adjustments to a changing environment.

We find that forced CEO turnover, and the performance sensitivity of forced CEO turnover, increase in the 3 years immediately following major tariff cuts, but the effects dissipate thereafter. We find that the likelihood of forced turnover is higher for firms that are more exposed to rival strategies such as predation or market-stealing. When we examine how corporate governance quality affects forced turnover and turnover-performance sensitivity, we find that the effects are concentrated in firms with weaker governance. This is consistent with the notion that, under normal times, weak boards tolerate slack and inefficiency. However, since it is difficult for profligate CEOs to acquire cost-cutting skills quickly or to change the way they are used to running their companies, replacing them becomes more imperative when competition from more cost-efficient foreign rivals threatens survival. Performance improves on a number of dimensions after the turnover, relative to a matched sample of firms with a similar propensity to experience turnover, but when no turnover occurs. Overall, these results suggest that firms do respond to increased competition by making organizational and top management changes that improve efficiency. 


\section{References}

Ali, A., S. Klasa, and E. Yeung. 2009. The limitations of industry concentration measures constructed with Compustat data: Implications for finance research. Review of Financial Studies 22:3839-71.

Bebchuk, L. A. 2003. The case for shareholder access to the ballot. Business Lawyer 59:43-66.

Bebchuk, L. A., A. Cohen, and A. Ferrell. 2009. What matters in corporate governance? Review of Financial Studies 22:783-827.

Benoit, J. 1984. Financially constrained entry in a game with incomplete information. Rand Journal of Economics 15:490-99.

Bertrand, M., and S. Mullainathan. 2003. Enjoying the quite life? Corporate governance and managerial preferences. Journal of Political Economy 111:1043-75.

Bloom, N., R. Sadun, and J. Van Reenen. 2010. Does product market competition lead firms to decentralize? American Economic Review 100:434-38.

Bolton, P., and D. Scharfstein. 1990. A theory of predation based on agency problems in financial contracting. A

merican Economic Review 80:93-106.

Bustos, P. 2011. Trade liberalization, exports, and technology upgrading: Evidence on the impact of MERCOSUR on Argentinian firms. American Economic Review 101:304-40.

Cai, J., J. L. Garner, and R. A. Walkling. 2009. Electing directors. Journal of Finance 64:2387-419.

Chevalier, J. 1995. Do LBO supermarkets charge more? An empirical analysis of the effects of LBOs on supermarket pricing. Journal of Finance 50:1095-112.

Cuñat, V., and M. Guadalupe. 2009. Globalization and the provision of incentives inside the firm: The effect of foreign competition. Journal of Labor Economics 27:179-212.

DeFond, M., and C. Park. 1999. The effect of competition on CEO turnover. Journal of Accounting and Economics 27:35-56.

Del Guercio, D., L. Seery, and T. Woidtke. 2008. Do boards pay attention when institutional investors 'just vote no'? CEO and director turnover associated with shareholder activism. Journal of Financial Economics 90:84-103.

Denis, D. J., D. K. Denis, and A. Sarin. 1997. Ownership structure and top executive turnover. Journal of Financial Economics 45:193-222.

Destler, I. M. 2005. American trade politics, 4th edition. Washington, DC: Institute for International Economics.

Feenstra, R. 1996. US imports, 1972-1994: Data and concordances. Unpublished Working Paper, National Bureau of Economic Research.

Feenstra, R., J. Romalis, and P. Schott. 2002. US imports, exports, and tariff data. Unpublished Working Paper, National Bureau of Economic Research. 
Frésard, L. 2010. Financial strength and product market behavior: The real effects of corporate cashholdings. Journal of Finance 65:1097-122.

Frésard, L., and P. Valta. 2012. Competitive pressure and corporate policies. Unpublished Working Paper, University of Maryland.

--------. 2015. How does corporate investment respond to increased entry threat? Review of Corporate Finance Studies 5:1-35.

Giroud, X., and H. Mueller. 2010. Does corporate governance matter in competitive industries? Journal of Financial Economics 95:312-31.

---------. 2011. Corporate governance, product market competition, and equity prices. Journal of Finance 66:563-600.

Gompers, P. A., J. L. Ishii, and A. Metrick. 2003. Corporate governance and equity prices. Quarterly Journal of Economics 118:107-55.

Greene, W. 2004. The behavior of the fixed effects estimator in nonlinear models. Econometrics Journal 7:98-119.

Guadalupe, M., and F. Perez-Gonzalez. 2010. Competition and private benefits of control. Unpublished Working Paper, Stanford University.

Harford, J. 2005. What drives merger waves? Journal of Financial Economics 77:529-60.

Harford, J., D. Jenter, and K. Li. 2011. Institutional cross-holdings and their effect on acquisition decisions. Journal of Financial Economics 99:27-39.

Hermalin, B., and M. Weisbach. 1998. Endogenously chosen boards of directors and their monitoring of the CEO. American Economic Review 88:96-118.

2003. Boards of directors as an endogenously determined institution: A survey of the economic literature. Economic Policy Review 9:7-26.

Hirshleifer, D., and A. Thakor. 1994. Managerial performance, boards of directors and takeover bidding. Journal of Corporate Finance 1:63-90.

--------. 1998. Corporate control through board dismissals and takeovers. Journal of Economics and Management Strategy 7:489-520.

Hoberg, G., and G. Phillips. 2016. Text-based network industries and endogenous product differentiation. Journal of Political Economy 124:1423-65.

Jenter, D., and F. Kanaan. 2015. CEO turnover and relative performance evaluation. Journal of Finance 70:2155-83.

Jenter, D., and K. Lewellen. 2014. Performance-induced CEO turnover. Unpublished Working Paper, Stanford University. 
Kale, J. R., E. Reis, and A. Venkateswaran. 2009. Rank-order tournaments and incentive alignment: The effect on firm performance. Journal of Finance 64:1479-512.

Kaplan, S., and B. Minton. 2012. How has CEO turnover changed? International Review of Finance 12:5787.

Kini, O., and R. Williams. 2012. Tournament incentives, firm risk, and corporate policies. Journal of Financial Economics 103:350-76.

Morck, R., A. Shleifer and R. Vishny. 1989, Management entrenchment: The case of manager-specific investments, Journal of Financial Economics 25:123-39.

Nickell, S. J. 1996. Competition and corporate performance. Journal of Political Economy 104:724-46.

Ovtchinnikov, A. 2010. Capital structure decisions: Evidence from deregulated industries. Journal of Financial Economics 95:249-74.

Parrino, R., R. W. Sias, and L. T. Starks. 2003. Voting with their feet: Ownership changes around the time of CEO turnover. Journal of Financial Economics 68:3-46.

Raith, M. 2003. Competition, risk and, managerial incentives. American Economic Review 93:1425-36.

Schmidt, K. 1997. Managerial incentives and product market competition. Review of Economic Studies 64:191-213.

Schott, P. 2010. US manufacturing exports and imports by SIC and NAICS category and partner country, 1972-2005. Unpublished Working Paper, Yale School of Management.

Telser, L. 1966. Cutthroat competition and the long purse. Journal of Law and Economics 9:259-77.

Valta, P. 2012. Competition and the cost of debt. Journal of Financial Economics 105:661-82. 
Table 1

\section{MAIN TABLES}

Summary statistics

A. CEO turnover by year

\begin{tabular}{|c|c|c|c|c|c|c|c|}
\hline \multirow[b]{2}{*}{ Year } & \multicolumn{2}{|c|}{ Standard turnover } & \multicolumn{3}{|c|}{ Forced turnover } & \multicolumn{2}{|c|}{ Alternative forced turnover } \\
\hline & Number & $\begin{array}{l}\text { Unconditional } \\
\text { probability }\end{array}$ & \multicolumn{2}{|c|}{ Number } & $\begin{array}{c}\text { Unconditional } \\
\text { probability }\end{array}$ & Number & 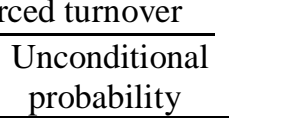 \\
\hline 1993 & 18 & 5.76 & \multicolumn{2}{|c|}{5} & 1.45 & 11 & 3.92 \\
\hline 1994 & 52 & 11.56 & \multicolumn{2}{|c|}{19} & 4.36 & 28 & 6.27 \\
\hline 1995 & 59 & 12.46 & \multicolumn{2}{|c|}{18} & 3.96 & 39 & 8.29 \\
\hline 1996 & 70 & 13.61 & \multicolumn{2}{|c|}{20} & 4.31 & 46 & 8.61 \\
\hline 1997 & 89 & 16.78 & \multicolumn{2}{|c|}{32} & 6.88 & 56 & 9.87 \\
\hline 1998 & 95 & 17.52 & \multicolumn{2}{|c|}{33} & 6.90 & 62 & 10.71 \\
\hline 1999 & 123 & 20.05 & \multicolumn{2}{|c|}{38} & 7.77 & 75 & 10.91 \\
\hline 2000 & 94 & 17.90 & \multicolumn{2}{|c|}{27} & 5.51 & 53 & 9.81 \\
\hline 2001 & 67 & 11.79 & \multicolumn{2}{|c|}{22} & 4.67 & 52 & 8.34 \\
\hline 2002 & 69 & 13.06 & \multicolumn{2}{|c|}{18} & 3.88 & 45 & 8.26 \\
\hline 2003 & 64 & 12.55 & \multicolumn{2}{|c|}{20} & 4.22 & 42 & 8.05 \\
\hline 2004 & 86 & 15.18 & \multicolumn{2}{|c|}{18} & 3.90 & 46 & 7.67 \\
\hline 2005 & 88 & 15.42 & 1 & & 2.46 & 58 & 9.92 \\
\hline 1993-2005 & 974 & 14.13 & 28 & & 4.64 & 613 & 8.51 \\
\hline B. Descriptive & statistics & & & & & & \\
\hline Variable & & Number & Mean & SD & 25 th percentile & 50th percentile & 75th percentile \\
\hline Tariff $(\%)$ & & 6,990 & 4.887 & 5.817 & 1.207 & 3.253 & 6.149 \\
\hline ROA & & 6,990 & 0.030 & 0.131 & 0.126 & 0.053 & 0.091 \\
\hline RET & & 6,803 & 0.164 & 0.553 & -0.151 & 0.088 & 0.348 \\
\hline Salechg & & 6,978 & 0.147 & 0.906 & -0.005 & 0.075 & 0.185 \\
\hline Assets & & 6,994 & 7.143 & 1.597 & 6.042 & 7.044 & 8.141 \\
\hline$q$ & & 6,863 & 2.261 & 2.166 & 1.276 & 1.684 & 2.486 \\
\hline Age & & 6,999 & 56.105 & 7.729 & 51 & 56 & 61 \\
\hline Volatility & & 6,263 & 0.447 & 0.251 & 0.277 & 0.373 & 0.556 \\
\hline CEO tenure & & 6,999 & 7.287 & 3.357 & 5 & 6 & 9 \\
\hline Institutional & ownership & 6,999 & 0.631 & 0.219 & 0.493 & 0.652 & 0.781 \\
\hline G-index & & 6,623 & 9.036 & 2.715 & 7 & 9 & 11 \\
\hline HHI & & 6,425 & 0.195 & 0.167 & 0.065 & 0.141 & 0.267 \\
\hline Board size & & 4,560 & 9.261 & 2.458 & 7 & 9 & 11 \\
\hline Board indep & ndence & 4,553 & 0.664 & 0.171 & 0.556 & 0.7 & 0.8 \\
\hline
\end{tabular}

The sample consists of all firms in manufacturing industries (200-399 standard industrial classification range) that also have data available on the ExecuComp database between 1993 and 2005. Panel A summarizes CEO turnover for our sample firms. Standard turnover is the sum of forced and voluntary turnover. Under each turnover type, we report the number and the unconditional probability (in percentages). Tariff is the duties collected by the US Customs Service divided by the free-on-board value of imports (in percentages). Forced turnovers are defined in Parrino, Sias, and Starks (2003), with an additional filter: departures of chief executive officers (CEOs) before age 60 and for which we cannot find any record of another position, including directorial appointments, are classified as forced. Alternative 
forced turnovers are all forced turnovers defined as above plus other turnovers that result in a lower pay at a smaller firm for the departing CEOs. Table A1 defines all other variables.

Downloaded from https://academic.oup.com/rfs/advance-article-abstract/doi/10.1093/rfs/hhx129/4708265 by Health Sciences Library System user

on 18 December 2017 
Table 2

Tariff cuts and CEO forced turnover

\begin{tabular}{|c|c|c|c|c|c|c|c|c|}
\hline Variable & $(1)$ & $(2)$ & (3) & $(4)$ & $(5)$ & $(6)$ & $(7)$ & $(8)$ \\
\hline & & & & & & & Placebo & Placebo \\
\hline CUT_POST3 & & $\begin{array}{c}0.038 * * * \\
(0.004)\end{array}$ & $\begin{array}{c}0.020 * * * \\
(0.005)\end{array}$ & $\begin{array}{c}0.012 * * \\
(0.006)\end{array}$ & $\begin{array}{c}0.018 * * * \\
(0.005)\end{array}$ & $\begin{array}{c}0.008 * * \\
(0.003)\end{array}$ & $\begin{array}{c}0.005 \\
(0.005)\end{array}$ & $\begin{array}{c}0.004 \\
(0.006)\end{array}$ \\
\hline CUT_POST3 $*$ IND_ADJ_ROA & & & & & $\begin{array}{c}-0.028 * * * \\
(0.007)\end{array}$ & $\begin{array}{c}-0.013 * * \\
(0.005)\end{array}$ & & $\begin{array}{l}-0.021 \\
(0.049)\end{array}$ \\
\hline CUT_POST3 $*$ IND_ADJ_RET & & & & & $\begin{array}{c}-0.014 * * \\
(0.006)\end{array}$ & $\begin{array}{c}-0.024 * * * \\
(0.007)\end{array}$ & & $\begin{array}{l}-0.018 \\
(0.019)\end{array}$ \\
\hline IND_ADJ_ROA & $\begin{array}{c}-0.074 * * * \\
(0.017)\end{array}$ & & $\begin{array}{c}-0.082 * * * \\
(0.018)\end{array}$ & $\begin{array}{c}-0.063^{* *} \\
(0.026)\end{array}$ & $\begin{array}{c}-0.104 * * * \\
(0.020)\end{array}$ & $\begin{array}{c}-0.065^{* *} \\
(0.028)\end{array}$ & $\begin{array}{c}-0.081 * * * \\
(0.018)\end{array}$ & $\begin{array}{c}-0.104 * * * \\
(0.019)\end{array}$ \\
\hline IND_ADJ_RET & $\begin{array}{c}-0.051 * * * \\
(0.003)\end{array}$ & & $\begin{array}{c}-0.054 * * * \\
(0.003)\end{array}$ & $\begin{array}{c}-0.077 * * * \\
(0.005)\end{array}$ & $\begin{array}{c}-0.051 * * * \\
(0.004)\end{array}$ & $\begin{array}{c}-0.083 * * * \\
(0.006)\end{array}$ & $\begin{array}{c}-0.054 * * * \\
(0.003)\end{array}$ & $\begin{array}{c}-0.052 * * * \\
(0.004)\end{array}$ \\
\hline Salechg & $\begin{array}{c}-0.015 * * * \\
(0.005)\end{array}$ & & $\begin{array}{c}-0.015 * * * \\
(0.005)\end{array}$ & $\begin{array}{c}-0.019 * * \\
(0.008)\end{array}$ & $\begin{array}{c}-0.017 * * * \\
(0.005)\end{array}$ & $\begin{array}{c}-0.018^{* *} \\
(0.008)\end{array}$ & $\begin{array}{c}-0.015 * * * \\
(0.005)\end{array}$ & $\begin{array}{c}-0.012 * * \\
(0.005)\end{array}$ \\
\hline Salechg * CUT_POST3 & & & & & $\begin{array}{l}-0.008 \\
(0.006)\end{array}$ & $\begin{array}{l}-0.005 \\
(0.008)\end{array}$ & & $\begin{array}{l}-0.021 \\
(0.015)\end{array}$ \\
\hline Assets & $\begin{array}{c}0.013 * * * \\
(0.005)\end{array}$ & & $\begin{array}{l}0.009 * \\
(0.005)\end{array}$ & $\begin{array}{l}-0.005 \\
(0.009)\end{array}$ & $\begin{array}{c}0.008 \\
(0.005)\end{array}$ & $\begin{array}{c}0.005 \\
(0.009)\end{array}$ & $\begin{array}{c}0.011 * * \\
(0.005)\end{array}$ & $\begin{array}{c}0.011 * * \\
(0.005)\end{array}$ \\
\hline Assets * CUT_POST3 & & & & & $\begin{array}{c}0.003 \\
(0.004)\end{array}$ & $\begin{array}{l}-0.006 \\
(0.010)\end{array}$ & & $\begin{array}{c}-0.004 \\
(0.004)\end{array}$ \\
\hline$q$ & $\begin{array}{c}0.002 * * \\
(0.001)\end{array}$ & & $\begin{array}{l}0.002 * \\
(0.001)\end{array}$ & $\begin{array}{c}0.006 * * * \\
(0.001)\end{array}$ & $\begin{array}{l}0.002 * \\
(0.001)\end{array}$ & $\begin{array}{c}0.005^{* * * *} \\
(0.002)\end{array}$ & $\begin{array}{c}0.002 * * \\
(0.001)\end{array}$ & $\begin{array}{c}0.001 \\
(0.001)\end{array}$ \\
\hline$q *$ CUT_POST3 & & & & & $\begin{array}{c}0.001 \\
(0.002)\end{array}$ & $\begin{array}{c}0.003 \\
(0.003)\end{array}$ & & $\begin{array}{c}0.006 \\
(0.004)\end{array}$ \\
\hline Age_dummy & $\begin{array}{c}0.172 * * * \\
(0.004)\end{array}$ & & $\begin{array}{c}0.174 * * * \\
(0.004)\end{array}$ & $\begin{array}{c}0.230 * * * \\
(0.006)\end{array}$ & $\begin{array}{c}0.169 * * * \\
(0.004)\end{array}$ & $\begin{array}{c}0.223 * * * \\
(0.006)\end{array}$ & $\begin{array}{c}0.175 * * * \\
(0.004)\end{array}$ & $\begin{array}{c}0.172 * * * \\
(0.004)\end{array}$ \\
\hline Age_dummy $*$ CUT_POST3 & & & & & $\begin{array}{c}0.037 * * * \\
(0.009)\end{array}$ & $\begin{array}{c}0.106^{* * * *} \\
(0.018)\end{array}$ & & $\begin{array}{c}0.035 \\
(0.021)\end{array}$ \\
\hline Volatility & $\begin{array}{c}0.122 * * * \\
(0.018)\end{array}$ & & $\begin{array}{c}0.125 * * * \\
(0.019)\end{array}$ & $\begin{array}{c}0.279 * * * \\
(0.035)\end{array}$ & $\begin{array}{c}0.099 * * * \\
(0.020)\end{array}$ & $\begin{array}{c}0.271 * * * \\
(0.036)\end{array}$ & $\begin{array}{c}0.125^{* * * *} \\
(0.019)\end{array}$ & $\begin{array}{c}0.113^{* * * *} \\
(0.020)\end{array}$ \\
\hline Volatility *CUT_POST3 & & & & & $\begin{array}{c}0.036 \\
(0.025)\end{array}$ & $\begin{array}{c}-0.091 * \\
(0.052)\end{array}$ & & $\begin{array}{c}0.019 \\
(0.029)\end{array}$ \\
\hline CEO tenure & $0.008 * * *$ & & $0.009 * * *$ & $0.011 * * *$ & $0.008 * * *$ & $0.011 * * *$ & $0.009 * * *$ & $0.009 * * *$ \\
\hline
\end{tabular}




\begin{tabular}{|c|c|c|c|c|c|c|c|c|}
\hline CEO tenure $*$ CUT_POST3 & $(0.001)$ & & $(0.001)$ & $(0.001)$ & $\begin{array}{c}(0.001) \\
0.019 \\
(0.012)\end{array}$ & $\begin{array}{l}(0.001) \\
0.010^{*} \\
(0.007)\end{array}$ & $(0.001)$ & $\begin{array}{c}(0.001) \\
0.015 \\
(0.013)\end{array}$ \\
\hline Institutional ownership & $\begin{array}{c}-0.103 * * * \\
(0.012)\end{array}$ & & $\begin{array}{c}-0.080 * * * \\
(0.012)\end{array}$ & $\begin{array}{c}-0.055^{* * *} \\
(0.020)\end{array}$ & $\begin{array}{c}-0.085^{* * *} * \\
(0.013)\end{array}$ & $\begin{array}{c}-0.063 * * * \\
(0.021)\end{array}$ & $\begin{array}{c}-0.082 * * * \\
(0.012)\end{array}$ & $\begin{array}{c}-0.084 * * * \\
(0.012)\end{array}$ \\
\hline Institutional ownership * CUT_POST3 & & & & & $\begin{array}{l}0.064 * \\
(0.052)\end{array}$ & $\begin{array}{c}0.049 \\
(0.046)\end{array}$ & & $\begin{array}{c}0.044 \\
(0.030)\end{array}$ \\
\hline G-index & $\begin{array}{c}-0.012 * * * \\
(0.002)\end{array}$ & & $\begin{array}{c}-0.013 * * * \\
(0.002)\end{array}$ & $\begin{array}{c}-0.033 * * * \\
(0.003)\end{array}$ & $\begin{array}{c}-0.013 * * * \\
(0.002)\end{array}$ & $\begin{array}{c}-0.031 * * * \\
(0.003)\end{array}$ & $\begin{array}{c}-0.013 * * * \\
(0.002)\end{array}$ & $\begin{array}{c}-0.013 * * * \\
(0.002)\end{array}$ \\
\hline G-index * CUT_POST3 & & & & & $\begin{array}{c}-0.004 * * \\
(0.002)\end{array}$ & $\begin{array}{c}0.001 \\
(0.004)\end{array}$ & & $\begin{array}{l}-0.001 \\
(0.002)\end{array}$ \\
\hline HHI & $\begin{array}{c}-0.086 * * * \\
(0.030)\end{array}$ & & $\begin{array}{c}-0.194 * * * \\
(0.034)\end{array}$ & $\begin{array}{l}-0.064 \\
(0.053)\end{array}$ & $\begin{array}{c}-0.228 * * * \\
(0.034)\end{array}$ & $\begin{array}{l}-0.045 \\
(0.053)\end{array}$ & $\begin{array}{c}-0.184 * * * \\
(0.034)\end{array}$ & $\begin{array}{c}-0.199 * * * \\
(0.034)\end{array}$ \\
\hline HHI *CUT_POST3 & & & & & $\begin{array}{c}0.025 \\
(0.032)\end{array}$ & $\begin{array}{c}-0.157^{*} \\
(0.081)\end{array}$ & & $\begin{array}{c}0.014 \\
(0.037)\end{array}$ \\
\hline Board size & & & & $\begin{array}{c}0.018 * * * \\
(0.002)\end{array}$ & & $\begin{array}{c}0.016 * * * \\
(0.002)\end{array}$ & & \\
\hline Board size * CUT_POST3 & & & & & & $\begin{array}{l}-0.006 \\
(0.005)\end{array}$ & & \\
\hline Board independence & & & & $\begin{array}{c}-0.086 * * * \\
(0.025)\end{array}$ & & $\begin{array}{c}-0.074 * * * \\
(0.026)\end{array}$ & & \\
\hline Board independence * CUT_POST3 & & & & & & $\begin{array}{l}-0.005 \\
(0.007)\end{array}$ & & \\
\hline Year fixed effects & Yes & Yes & Yes & Yes & Yes & Yes & Yes & Yes \\
\hline Firm fixed effects & Yes & Yes & Yes & Yes & Yes & Yes & Yes & Yes \\
\hline$R^{2}$ & 0.11 & 0.02 & 0.11 & 0.12 & 0.15 & 0.16 & 0.11 & 0.11 \\
\hline Observations & 20,548 & 20,548 & 20,548 & 14,093 & 20,548 & 14,093 & 20,548 & 20,548 \\
\hline
\end{tabular}

This table reports the results of linear probability regression in which the dependent variable equals 1 if the CEO is forced to leave the firm in year $t$, and 0 otherwise. CUT_POST3 is a dummy variable that equals 1 for the first 3 years after an industry has experienced a tariff rate reduction larger than 3 times the median tariff rate reduction in the same industry, and 0 otherwise. In Columns 7 and 8, we assign tariff cut events randomly to perform a placebo test. Table A1 defines all other variables, which are measured at 1-year lags. Year and firm fixed effects are included in all columns. Robust standard errors, clustered by 3-digit standard industrial classification (SIC) codes, are in parentheses. ${ }^{* *}$, and *** indicate significance at the $10 \%, 5 \%$, and $1 \%$ level, respectively. 
Table 3

Predation threat

A. Turnover

\begin{tabular}{|c|c|c|c|c|c|c|}
\hline \multirow[b]{2}{*}{ Variable } & \multicolumn{2}{|c|}{ Financial flexibility } & \multicolumn{2}{|c|}{ Deep pockets } & \multicolumn{2}{|c|}{ similarity } \\
\hline & $\begin{array}{c}\text { Low } \\
(1)\end{array}$ & $\begin{array}{l}\text { High } \\
(2) \\
\end{array}$ & $\begin{array}{c}\text { Low } \\
(3) \\
\end{array}$ & $\begin{array}{c}\text { High } \\
(4)\end{array}$ & $\begin{array}{c}\text { Low } \\
(5) \\
\end{array}$ & $\begin{array}{c}\text { High } \\
(6)\end{array}$ \\
\hline CUT_POST3 & $\begin{array}{c}0.014 \\
(0.010)\end{array}$ & $\begin{array}{c}0.028 * * \\
(0.012)\end{array}$ & $\begin{array}{c}0.006 \\
(0.012)\end{array}$ & $\begin{array}{c}0.030 * * * \\
(0.007)\end{array}$ & $\begin{array}{c}0.008 \\
(0.007)\end{array}$ & $\begin{array}{c}0.026 * * * \\
(0.007)\end{array}$ \\
\hline Wald $\chi 2$ test for CUT_POST3 ( $p$-value) & & .08 & & .01 & & .02 \\
\hline Other control variables & Yes & Yes & Yes & Yes & Yes & Yes \\
\hline Year fixed effects & Yes & Yes & Yes & Yes & Yes & Yes \\
\hline Firm fixed effects & Yes & Yes & Yes & Yes & Yes & Yes \\
\hline$R^{2}$ & 0.16 & 0.12 & 0.17 & 0.12 & 0.15 & 0.12 \\
\hline Observations & 7,636 & 13,812 & 8,012 & 12,536 & 12,744 & 7,804 \\
\hline
\end{tabular}




\begin{tabular}{|c|c|c|c|c|c|c|}
\hline \multirow[b]{2}{*}{ Variable } & \multicolumn{2}{|c|}{ Financial flexibility } & \multicolumn{2}{|c|}{ Deep pockets } & \multicolumn{2}{|c|}{ Similarity } \\
\hline & $\begin{array}{c}\text { Low } \\
(1) \\
\end{array}$ & $\begin{array}{l}\text { High } \\
(2)\end{array}$ & $\begin{array}{c}\text { Low } \\
(3)\end{array}$ & $\begin{array}{l}\text { High } \\
(4)\end{array}$ & $\begin{array}{c}\text { Low } \\
(5)\end{array}$ & $\begin{array}{c}\text { High } \\
(6)\end{array}$ \\
\hline CUT_POST3 & $\begin{array}{c}0.012 \\
(0.010)\end{array}$ & $\begin{array}{c}0.024 * * \\
(0.009)\end{array}$ & $\begin{array}{c}0.005 \\
(0.010)\end{array}$ & $\begin{array}{c}0.026^{* * *} \\
(0.007)\end{array}$ & $\begin{array}{c}0.007 \\
(0.011)\end{array}$ & $\begin{array}{c}0.023 * * * \\
(0.007)\end{array}$ \\
\hline CUT_POST3 $*$ IND_ADJ_ROA & $\begin{array}{l}-0.009 * \\
(0.005)\end{array}$ & $\begin{array}{c}-0.028 * * * \\
(0.007)\end{array}$ & $\begin{array}{l}-0.015 \\
(0.049)\end{array}$ & $\begin{array}{c}-0.033 * * * \\
(0.007)\end{array}$ & $\begin{array}{c}0.009 \\
(0.008)\end{array}$ & $\begin{array}{c}-0.023 * * * \\
(0.007)\end{array}$ \\
\hline CUT_POST3 $*$ IND_ADJ_RET & $\begin{array}{c}0.007 \\
(0.012)\end{array}$ & $\begin{array}{c}-0.022 * * \\
(0.009)\end{array}$ & $\begin{array}{c}-0.024 * * \\
(0.011)\end{array}$ & $\begin{array}{c}-0.038 * * * \\
(0.009)\end{array}$ & $\begin{array}{c}-0.011 \\
(0.011)\end{array}$ & $\begin{array}{c}-0.038 * * \\
(0.019)\end{array}$ \\
\hline IND_ADJ_ROA & $\begin{array}{c}-0.073 * * \\
(0.029)\end{array}$ & $\begin{array}{c}-0.211 * * * \\
(0.028)\end{array}$ & $\begin{array}{c}-0.073 * * \\
(0.028)\end{array}$ & $\begin{array}{c}-0.238 * * * \\
(0.032)\end{array}$ & $\begin{array}{c}-0.103 * * * \\
(0.025)\end{array}$ & $\begin{array}{c}-0.196 * * * \\
(0.042)\end{array}$ \\
\hline IND_ADJ_RET & $\begin{array}{c}-0.044 * * * \\
(0.008)\end{array}$ & $\begin{array}{c}-0.057 * * * \\
(0.005)\end{array}$ & $\begin{array}{c}-0.045 * * * \\
(0.007)\end{array}$ & $\begin{array}{c}-0.081 * * * \\
(0.005)\end{array}$ & $\begin{array}{c}-0.080 * * * \\
(0.005)\end{array}$ & $\begin{array}{c}-0.068 * * * \\
(0.007)\end{array}$ \\
\hline Wald $\chi 2$ for CUT_POST3 $*$ IND_ADJ_ROA ( $p$-value $)$ & & .07 & & .01 & & .05 \\
\hline Wald $\chi 2$ for CUT_POST3 $*$ IND_ADJ_RET ( $p$-value $)$ & & .02 & & .12 & & .07 \\
\hline Other control variables & Yes & Yes & Yes & Yes & Yes & Yes \\
\hline Year fixed effects & Yes & Yes & Yes & Yes & Yes & Yes \\
\hline Firm fixed effects & Yes & Yes & Yes & Yes & Yes & Yes \\
\hline$R^{2}$ & 0.16 & 0.13 & 0.18 & 0.12 & 0.15 & 0.13 \\
\hline Observations & 7,636 & 13,812 & 8,012 & 12,536 & 12,744 & 7,804 \\
\hline
\end{tabular}

This table reports the results of linear probability regression in which the dependent variable equals 1 if the CEO is forced to leave the firm in year $t$, and 0 otherwise. CUT_POST3 is a dummy variable that equals 1 for the first 3 years after an industry has experienced a tariff rate reduction larger than 3 times the median tariff rate reduction in the same industry, and 0 otherwise. Financial flexibility is the percentage of industry sales contributed by firms above the 75 th percentile of the industry cash to assets ratio. Deep pockets is the percentage of industry sales contributed by firms below the 25 th percentile of the industry leverage ratio. Similarity is the firm-level total similarity index based on Hoberg and Phillips (2011) and on the comparison of product descriptions in firms' 10-K annual filings with the cosine similarity method. In Columns 1 and 2, all firms are divided into two subgroups based on whether Financial flexibility of the industry in which the firm operates in the year before is below (low) or above (high) the sample average. In Columns 3 and 4, all firms are divided into two subgroups based on whether Deep pockets of the industry in which the firm operates in the year before is below (low) or above (high) the sample average. Columns 5 and 6 contain firms with Similarity in the year before below (low) or above (high) the mean of all firms in the same industry (3-digit SIC code). All other control variables are the same as those in Columns 3 and 5 in Table 2 and are defined in Table A1. Year and firm fixed effects are included in all columns. Robust standard errors, clustered by 3digit SIC codes, are in parentheses. $* * *$, and $* * *$ indicate significance at the $10 \%, 5 \%$, and $1 \%$ level, respectively. 
Table 4

Governance proxies, productivity and default likelihood

A. Row percentage

\begin{tabular}{|c|c|c|c|c|c|}
\hline \multirow[t]{2}{*}{ TFP } & \multicolumn{2}{|c|}{ G-index } & \multirow[t]{2}{*}{ Z-Score } & \multicolumn{2}{|c|}{ G-index } \\
\hline & High & Low & & High & Low \\
\hline Low & $56.8 \%$ & $41.1 \%$ & Low & $55.2 \%$ & $44.7 \%$ \\
\hline \multirow[t]{3}{*}{ High } & $43.2 \%$ & $58.9 \%$ & High & $44.8 \%$ & $55.3 \%$ \\
\hline & \multicolumn{2}{|c|}{ E-index } & & \multicolumn{2}{|c|}{ E-index } \\
\hline & High & low & & High & Low \\
\hline Low & $53.2 \%$ & $42.3 \%$ & Low & $57.7 \%$ & $44.9 \%$ \\
\hline \multirow[t]{3}{*}{ High } & $46.8 \%$ & $57.7 \%$ & High & $42.3 \%$ & $55.1 \%$ \\
\hline & \multicolumn{2}{|c|}{ Independence } & & \multicolumn{2}{|c|}{ Independence } \\
\hline & Low & High & & Low & High \\
\hline Low & $55.1 \%$ & $41.4 \%$ & Low & $55.8 \%$ & $43.9 \%$ \\
\hline \multirow[t]{3}{*}{ High } & $44.9 \%$ & $58.6 \%$ & High & $44.2 \%$ & $56.1 \%$ \\
\hline & \multicolumn{2}{|c|}{ Institutional } & & \multicolumn{2}{|c|}{ Institutional } \\
\hline & Low & High & & Low & High \\
\hline Low & $58.2 \%$ & $44.9 \%$ & Low & $56.5 \%$ & $42.6 \%$ \\
\hline High & $41.8 \%$ & $55.1 \%$ & High & $43.5 \%$ & $57.4 \%$ \\
\hline \multicolumn{6}{|c|}{ B. Column percentage } \\
\hline \multirow[t]{2}{*}{ TFP } & \multicolumn{2}{|c|}{ G-index } & Z-Score & \multicolumn{2}{|c|}{ G-index } \\
\hline & High & Low & & High & Low \\
\hline Low & $53.6 \%$ & $46.4 \%$ & Low & $55.3 \%$ & $44.7 \%$ \\
\hline \multirow[t]{3}{*}{ High } & $38.0 \%$ & $62.0 \%$ & High & $44.8 \%$ & $55.2 \%$ \\
\hline & \multicolumn{2}{|c|}{ E-index } & & \multicolumn{2}{|c|}{ E-index } \\
\hline & High & Low & & High & Low \\
\hline Low & $57.0 \%$ & $43.0 \%$ & Low & $56.6 \%$ & $43.4 \%$ \\
\hline \multirow[t]{3}{*}{ High } & $46.1 \%$ & $53.9 \%$ & High & $43.8 \%$ & $56.2 \%$ \\
\hline & \multicolumn{2}{|c|}{ Independence } & & \multicolumn{2}{|c|}{ Independence } \\
\hline & Low & High & & Low & High \\
\hline Low & $55.9 \%$ & $44.1 \%$ & Low & $55.8 \%$ & $44.2 \%$ \\
\hline \multirow[t]{3}{*}{ High } & $42.2 \%$ & $57.8 \%$ & High & $43.9 \%$ & $56.1 \%$ \\
\hline & \multicolumn{2}{|c|}{ Institutional } & & \multicolumn{2}{|c|}{ Institutional } \\
\hline & Low & High & & Low & High \\
\hline Low & $58.0 \%$ & $42.0 \%$ & Low & $56.3 \%$ & $43.7 \%$ \\
\hline High & $44.7 \%$ & $55.3 \%$ & High & $42.4 \%$ & $57.6 \%$ \\
\hline
\end{tabular}

This table presents the two-way distribution of our sample firms partitioned by governance and productivity or probability of default. TFP is total factor productivity. z-score is based on Altman (1967) that combines five financial ratios to estimate the likelihood of bankruptcy. G-index is the governance index based on Gompers, Ishii, and Metrick (2003). E-index is the entrenchment index based on Bebchuk, Cohen, and Ferrell (2009). Independence is the proportion of independent directors on the board. Institutional measures the sum of ownership of all institutional investors who hold the firm's stock. In each year, we partition our sample firms into two groups based on the value of the governance proxy as of the previous year. We define poor (good) governance firms as those with Independence or Institutional below (above) the industry mean or $G$-index or E-index above (below) the industry mean. In a similar way, we partition our samples firms into high (low) productivity firms based on the value of TFP above (below) the industry mean. We also define high (low) probability of default firms based on the value of z-score below (above) the industry mean. Panel A reports the percentage of high and low productivity or probability of default firms in each of the governance group (row percentage). Panel B reports the percentage of poor and good governance firms in each of the TFP or Z-score group (column percentage). 
Table 5

Tariff cuts, corporate governance, and CEO forced turnover

\begin{tabular}{|c|c|c|c|c|c|c|c|c|}
\hline \multirow[b]{2}{*}{ Variable } & \multicolumn{2}{|c|}{ G-index } & \multicolumn{2}{|c|}{ E-index } & \multicolumn{2}{|c|}{ Independence } & \multicolumn{2}{|c|}{ Institutional } \\
\hline & $\begin{array}{l}\text { High } \\
(1)\end{array}$ & $\begin{array}{c}\text { Low } \\
(2) \\
\end{array}$ & $\begin{array}{l}\text { High } \\
(3)\end{array}$ & $\begin{array}{c}\text { Low } \\
(4) \\
\end{array}$ & $\begin{array}{c}\text { Low } \\
(5) \\
\end{array}$ & $\begin{array}{c}\text { High } \\
(6) \\
\end{array}$ & $\begin{array}{c}\text { Low } \\
(7)\end{array}$ & $\begin{array}{c}\text { High } \\
(8) \\
\end{array}$ \\
\hline CUT_POST3 & $\begin{array}{c}0.032 * * * \\
(0.008)\end{array}$ & $\begin{array}{c}0.007 \\
(0.011)\end{array}$ & $\begin{array}{c}0.024 * * * \\
(0.006)\end{array}$ & $\begin{array}{c}0.008 \\
(0.013)\end{array}$ & $\begin{array}{c}0.037 * * \\
(0.017)\end{array}$ & $\begin{array}{c}0.013 * * \\
(0.006)\end{array}$ & $\begin{array}{c}0.032 * * * \\
(0.009)\end{array}$ & $\begin{array}{c}0.009 \\
(0.008)\end{array}$ \\
\hline Wald $\chi 2$ test for CUT_POST3 ( $p$-value) & & .06 & & .01 & & .16 & & .04 \\
\hline Other control variables & Yes & Yes & Yes & Yes & Yes & Yes & Yes & Yes \\
\hline Year fixed effects & Yes & Yes & Yes & Yes & Yes & Yes & Yes & Yes \\
\hline Firm fixed effects & Yes & Yes & Yes & Yes & Yes & Yes & Yes & Yes \\
\hline$R^{2}$ & 0.10 & 0.11 & 0.12 & 0.15 & 0.17 & 0.12 & 0.15 & 0.14 \\
\hline Observations & 11,940 & 8,608 & 14,019 & 6,529 & 4,820 & 9,273 & 10,866 & 9,682 \\
\hline
\end{tabular}




\begin{tabular}{|c|c|c|c|c|c|c|c|c|}
\hline \multirow[b]{2}{*}{ Variable } & \multicolumn{2}{|c|}{ G-index } & \multicolumn{2}{|c|}{ E-index } & \multicolumn{2}{|c|}{ Independence } & \multicolumn{2}{|c|}{ Institutional } \\
\hline & $\begin{array}{l}\text { High } \\
\text { (1) }\end{array}$ & $\begin{array}{c}\text { Low } \\
(2) \\
\end{array}$ & $\begin{array}{c}\text { High } \\
(3) \\
\end{array}$ & $\begin{array}{c}\text { Low } \\
(4)\end{array}$ & $\begin{array}{c}\text { Low } \\
(5) \\
\end{array}$ & $\begin{array}{c}\text { High } \\
(6) \\
\end{array}$ & $\begin{array}{c}\text { Low } \\
(7) \\
\end{array}$ & $\begin{array}{c}\text { High } \\
(8) \\
\end{array}$ \\
\hline CUT_POST3 & $\begin{array}{c}0.030 * * * \\
(0.008)\end{array}$ & $\begin{array}{c}0.006 \\
(0.008)\end{array}$ & $\begin{array}{c}0.020 * * * \\
(0.006)\end{array}$ & $\begin{array}{c}0.007 \\
(0.013)\end{array}$ & $\begin{array}{c}0.034 * * \\
(0.017)\end{array}$ & $\begin{array}{l}0.009 * \\
(0.005)\end{array}$ & $\begin{array}{c}0.029 * * \\
(0.010)\end{array}$ & $\begin{array}{c}0.010 \\
(0.008)\end{array}$ \\
\hline CUT_POST3 $*$ ROA & $\begin{array}{c}-0.025^{* *} \\
(0.008)\end{array}$ & $\begin{array}{l}-0.012 * \\
(0.007)\end{array}$ & $\begin{array}{c}-0.053 * * \\
(0.026)\end{array}$ & $\begin{array}{c}-0.023 * \\
(0.013)\end{array}$ & $\begin{array}{c}-0.039 * * \\
(0.016)\end{array}$ & $\begin{array}{c}-0.015 \\
(0.018)\end{array}$ & $\begin{array}{c}-0.035 * * * \\
(0.011)\end{array}$ & $\begin{array}{c}0.007 \\
(0.072)\end{array}$ \\
\hline CUT_POST3 $*$ RET & $\begin{array}{c}-0.021 * * \\
(0.009)\end{array}$ & $\begin{array}{c}0.002 \\
(0.009)\end{array}$ & $\begin{array}{c}-0.024 * \\
(0.013)\end{array}$ & $\begin{array}{l}-0.002 \\
(0.007)\end{array}$ & $\begin{array}{c}-0.023 * * \\
(0.008)\end{array}$ & $\begin{array}{l}-0.012 \\
(0.016)\end{array}$ & $\begin{array}{c}-0.037 * * * \\
(0.010)\end{array}$ & $\begin{array}{c}-0.023 * \\
(0.012)\end{array}$ \\
\hline IND_ADJ_ROA & $\begin{array}{c}-0.151 * * * \\
(0.024)\end{array}$ & $\begin{array}{c}-0.226 * * * \\
(0.036)\end{array}$ & $\begin{array}{c}-0.104 * * * \\
(0.022)\end{array}$ & $\begin{array}{c}-0.210 * * * \\
(0.047)\end{array}$ & $\begin{array}{c}-0.116^{* *} \\
(0.049)\end{array}$ & $\begin{array}{c}-0.198 * * * \\
(0.024)\end{array}$ & $\begin{array}{c}-0.177 * * * \\
(0.032)\end{array}$ & $\begin{array}{c}-0.103 * * * \\
(0.029)\end{array}$ \\
\hline IND_ADJ_RET & $\begin{array}{c}-0.046^{* * *} \\
(0.005)\end{array}$ & $\begin{array}{c}-0.042 * * * \\
(0.006)\end{array}$ & $\begin{array}{c}-0.032 * * * \\
(0.010)\end{array}$ & $\begin{array}{c}-0.056^{* * *} \\
(0.004)\end{array}$ & $\begin{array}{c}-0.046 * * * \\
(0.009)\end{array}$ & $\begin{array}{c}-0.037 * * * \\
(0.005)\end{array}$ & $\begin{array}{c}-0.074 * * * \\
(0.006)\end{array}$ & $\begin{array}{c}-0.043 * * * \\
(0.007)\end{array}$ \\
\hline Wald $\chi 2$ test for CUT_POST $3 *$ ROA ( $p$-value) & & .09 & & .15 & & .04 & & .01 \\
\hline Wald $\chi 2$ test for CUT_POST3 $*$ RET ( $p$-value) & & .01 & & .01 & & .03 & & .08 \\
\hline Other control variables & Yes & Yes & Yes & Yes & Yes & Yes & Yes & Yes \\
\hline Firm fixed effects & Yes & Yes & Yes & Yes & Yes & Yes & Yes & Yes \\
\hline Year fixed effects & Yes & Yes & Yes & Yes & Yes & Yes & Yes & Yes \\
\hline$R^{2}$ & 0.10 & 0.13 & 0.12 & 0.16 & 0.17 & 0.12 & 0.16 & 0.14 \\
\hline Observations & 11,940 & 8,608 & 14,019 & 6,529 & 4,820 & 9,273 & 10,866 & 9,682 \\
\hline
\end{tabular}

This table reports the results of linear probability regression in which the dependent variable equals 1 if the CEO is forced to leave the firm in year $t$, and 0 otherwise. CUT_POST3 is a dummy variable that equals 1 for the first 3 years after an industry has experienced a tariff rate reduction larger than 3 times the median tariff rate reduction in the same industry, and 0 otherwise. G-index is the governance index based on Gompers, Ishii, and Metrick (2003). E-index is the entrenchment index based on Bebchuk, Cohen, and Ferrell (2009). Independence is the proportion of independent directors on the board. Institutional measures the sum of ownership of all institutional investors who hold the firm's stock. For each proxy and for each year, all firms in the same industry (3-digit SIC codes) are divided into two subgroups based on whether the proxy in the year before is above (high) or below (low) the industry average. All other control variables are the same as those in Columns 3 and 5 of Table 2 and are defined in Table A1. Year and firm fixed effects are included in all columns. Robust standard errors, clustered by 3digit SIC codes, are in parentheses. *, **, and *** indicate significance at the $10 \%, 5 \%$, and $1 \%$ level, respectively. 


\section{Table 6}

Tariff cuts, board structure, and CEO forced turnover

A. Turnover

\begin{tabular}{lccc}
\hline & Director_Turnover & Classified & Independence \\
\cline { 2 - 4 } Variable & $(1)$ & $(2)$ & $(3)$ \\
CUT_POST3 & 0.017 & -0.006 & 0.048 \\
& $(0.015)$ & $(0.004)$ & $(0.035)$ \\
& & & \\
Other control variables & & & \\
Year fixed effects & Yes & Yes & Yes \\
Firm fixed effects & Yes & Yes & Yes \\
$R^{2}$ & Yes & Yes & Yes \\
Observations & 0.30 & 0.45 & 0.42 \\
\hline
\end{tabular}

Downloaded from https://academic.oup.com/rfs/advance-article-abstract/doi/10.1093/rfs/hhx129/4708265 
B. Tariff cut and board classification interactions

\begin{tabular}{|c|c|c|c|c|c|c|c|c|}
\hline \multirow[b]{2}{*}{ Variable } & \multicolumn{2}{|c|}{ G-index } & \multicolumn{2}{|c|}{ E-index } & \multicolumn{2}{|c|}{ Independence } & \multicolumn{2}{|c|}{ Institutional } \\
\hline & $\begin{array}{l}\text { High } \\
(1)\end{array}$ & $\begin{array}{l}\text { Low } \\
(2)\end{array}$ & $\begin{array}{l}\text { High } \\
(3)\end{array}$ & $\begin{array}{l}\text { Low } \\
(4)\end{array}$ & $\begin{array}{c}\text { Low } \\
(5)\end{array}$ & $\begin{array}{l}\text { High } \\
(6)\end{array}$ & $\begin{array}{l}\text { Low } \\
(7)\end{array}$ & $\begin{array}{c}\text { High } \\
(8)\end{array}$ \\
\hline CUT_POST3 & $\begin{array}{l}0.010^{*} \\
(0.005)\end{array}$ & $\begin{array}{c}0.007 \\
(0.016)\end{array}$ & $\begin{array}{c}0.014 \\
(0.012)\end{array}$ & $\begin{array}{c}0.010 \\
(0.019)\end{array}$ & $\begin{array}{c}0.018 \\
(0.012)\end{array}$ & $\begin{array}{l}0.015^{*} \\
(0.008)\end{array}$ & $\begin{array}{c}0.014 \\
(0.010)\end{array}$ & $\begin{array}{c}0.012 \\
(0.025)\end{array}$ \\
\hline Unclassified & $\begin{array}{c}-0.113 * * \\
(0.049)\end{array}$ & $\begin{array}{l}-0.041 \\
(0.026)\end{array}$ & $\begin{array}{l}-0.044 \\
(0.030)\end{array}$ & $\begin{array}{l}-0.061 \\
(0.070)\end{array}$ & $\begin{array}{c}0.045 \\
(0.055)\end{array}$ & $\begin{array}{c}0.023 \\
(0.026)\end{array}$ & $\begin{array}{l}-0.124 * * * \\
(0.032)\end{array}$ & $\begin{array}{c}0.014 \\
(0.036)\end{array}$ \\
\hline CUT_POST3 $*$ Unclassified & $\begin{array}{c}0.027^{* *} \\
(0.012)\end{array}$ & $\begin{array}{c}0.004 \\
(0.005)\end{array}$ & $\begin{array}{c}0.028 * * * \\
(0.005)\end{array}$ & $\begin{array}{c}0.008 \\
(0.020)\end{array}$ & $\begin{array}{l}0.033^{* *} \\
(0.014)\end{array}$ & $\begin{array}{l}-0.001 \\
(0.002)\end{array}$ & $\begin{array}{c}0.026^{* *} \\
(0.013)\end{array}$ & $\begin{array}{c}0.005 \\
(0.008)\end{array}$ \\
\hline $\begin{array}{l}\text { Wald } \chi 2 \text { test for CUT_POST3 } * \\
\text { Unclassified ( } p \text {-value) }\end{array}$ & & .06 & & .01 & & .03 & & .08 \\
\hline Other control variables & Yes & Yes & Yes & Yes & Yes & Yes & Yes & Yes \\
\hline Year fixed effects & Yes & Yes & Yes & Yes & Yes & Yes & Yes & Yes \\
\hline Firm fixed effects & Yes & Yes & Yes & Yes & Yes & Yes & Yes & Yes \\
\hline$R^{2}$ & 0.11 & 0.21 & 0.12 & 0.15 & 0.17 & 0.13 & 0.17 & 0.14 \\
\hline Observations & 6,872 & 4,663 & 7,844 & 3,690 & 3,944 & 7,590 & 6,103 & 5,432 \\
\hline $\begin{array}{l}\text { Panel A examines the change of boar } \\
\text { if the total number of departing and } i \\
\text { is a dummy variable that equals to } 1 \\
\text { is a dummy variable that equals to } 1 \\
\text { dummy variable that equals } 1 \text { for the } \\
\text { same industry, and } 0 \text { otherwise. In } p \\
\text { major tariff cut. Unclassified is a dun } \\
\text { turnover or board composition is not } \\
\text { are the same as those in Column } 3 \text { of } \\
\text { by 3-digit SIC codes, are in parenthe }\end{array}$ & $\begin{array}{l}\text { after the } t \\
\text { rectors ex } \\
\text { I classifice } \\
\text { any chang } \\
\text { s after an } \\
\text { exclude a } \\
\text { e that equ } \\
\text { forced CF } \\
\text { are defin } \\
\text { ind } * * * \text { in }\end{array}$ & $\begin{array}{l}\text { ut. The } \\
50 \% \text { of } \\
\text { tatus ha } \\
\text { he perce } \\
\text { try has e } \\
\text { is that h } \\
1 \text { if a fir } \\
\text { nover, } \\
\text { Table A } \\
\text { signific }\end{array}$ & $\begin{array}{l}\text { dent varia } \\
\text { ard size i } \\
\text { ged in ye } \\
\text { of indepe } \\
\text { enced a tal } \\
\text { anged bo } \\
\text { s not have } \\
\text { lude the ye } \\
\text { an and firm } \\
\text { at the } 10 \%\end{array}$ & $\begin{array}{l}\text { in Colum } \\
\text { ar } t \text {, and } \\
\text { and } 0 \text { otl } \\
\text { ent directc } \\
\text { rate reduc } \\
\text { classifica } \\
\text { lassified b } \\
\text { immedia }\end{array}$ & $\begin{array}{l}\text { Director } \\
\text { erwise. Tl } \\
\text { ise. The d } \\
\text { n the boar } \\
\text { larger that } \\
\text { status in } \mathrm{t} \\
\text { in the pric } \\
\text { after any } \mathrm{f}\end{array}$ & $\begin{array}{l}\text { over) is a } \\
\text { pendent } v \\
\text { dent varia } \\
\text { year } t \text {, an } \\
\text { mes the } \mathrm{n} \\
\text { st } 3 \text { years } \\
\text { ar, and } 0 \mathrm{c} \\
\text { CEO tur } \\
\text { Llumns }\end{array}$ & $\begin{array}{l}\text { amy variable } \\
\text { ble in Colum } \\
\text { in Column } 3 \\
\text { otherwise. } C \\
\text { an tariff rate } \\
\text { er an industr } \\
\text { wise. To ens } \\
\text { r. All other c } \\
\text { ust standard }\end{array}$ & $\begin{array}{l}\text { tequals to } \\
\text { (Classifie } \\
\text { dependenc } \\
\text { POST3 is } \\
\text { luction in tl } \\
\text { xperienced } \\
\text { that direct } \\
\text { trol variabl } \\
\text { ors, clustere }\end{array}$ \\
\hline
\end{tabular}


Table 7

Tariff cuts and CEO compensation

A. CEO compensation

\begin{tabular}{|c|c|c|c|c|c|}
\hline Variable & $\begin{array}{c}\text { Total_comp } \\
(1)\end{array}$ & $\begin{array}{c}\text { Short_comp } \\
(2)\end{array}$ & $\begin{array}{c}\text { Long_comp } \\
(3)\end{array}$ & $\begin{array}{c}\text { Alignment } \\
\text { (4) }\end{array}$ & $\begin{array}{c}\text { Pay_gap } \\
\text { (5) }\end{array}$ \\
\hline CUT_POST3 & $\begin{array}{c}0.018 \\
(0.014)\end{array}$ & $\begin{array}{l}-0.014 * \\
(0.008)\end{array}$ & $\begin{array}{l}-0.040 \\
(0.036)\end{array}$ & $\begin{array}{c}0.323 * * * \\
(0.071)\end{array}$ & $\begin{array}{c}0.257 * * * \\
(0.034)\end{array}$ \\
\hline IND_ADJ_ROA & $\begin{array}{c}0.306 * * * \\
(0.049)\end{array}$ & $\begin{array}{c}0.166 * * * \\
(0.030)\end{array}$ & $\begin{array}{c}0.638 * * * \\
(0.127)\end{array}$ & $\begin{array}{l}-0.155 \\
(0.253)\end{array}$ & $\begin{array}{c}0.381 * * * \\
(0.120)\end{array}$ \\
\hline IND_ADJ_RET & $\begin{array}{c}0.152 * * * \\
(0.008)\end{array}$ & $\begin{array}{c}0.098 * * * \\
(0.005)\end{array}$ & $\begin{array}{c}0.226 * * * \\
(0.022)\end{array}$ & $\begin{array}{l}-0.078^{*} \\
(0.044)\end{array}$ & $\begin{array}{c}0.269 * * * \\
(0.021)\end{array}$ \\
\hline Salechg & $\begin{array}{l}-0.004 \\
(0.013)\end{array}$ & $\begin{array}{c}0.002 \\
(0.008)\end{array}$ & $\begin{array}{c}-0.073 * * \\
(0.034)\end{array}$ & $\begin{array}{c}0.183 * * * \\
(0.067)\end{array}$ & $\begin{array}{c}-0.294 * * * \\
(0.032)\end{array}$ \\
\hline Assets & $\begin{array}{l}0.025^{*} \\
(0.013)\end{array}$ & $\begin{array}{c}0.003 \\
(0.008)\end{array}$ & $\begin{array}{c}0.036 \\
(0.034)\end{array}$ & $\begin{array}{c}-1.012 * * * \\
(0.068)\end{array}$ & $\begin{array}{c}-0.171 * * * \\
(0.032)\end{array}$ \\
\hline$q$ & $\begin{array}{c}0.058 * * * \\
(0.002)\end{array}$ & $\begin{array}{c}-0.006 * * * \\
(0.001)\end{array}$ & $\begin{array}{c}0.079 * * * \\
(0.006)\end{array}$ & $\begin{array}{c}0.055^{* * *} * \\
(0.013)\end{array}$ & $\begin{array}{c}0.050 * * * \\
(0.006)\end{array}$ \\
\hline CEO age & $\begin{array}{c}-0.012 * * * \\
(0.001)\end{array}$ & $\begin{array}{c}-0.007 * * * \\
(0.001)\end{array}$ & $\begin{array}{c}-0.017 * * * \\
(0.003)\end{array}$ & $\begin{array}{c}0.117 * * * \\
(0.005)\end{array}$ & $\begin{array}{c}-0.093 * * * \\
(0.002)\end{array}$ \\
\hline Volatility & $\begin{array}{c}-0.740 * * * \\
(0.051)\end{array}$ & $\begin{array}{c}-0.431 * * * \\
(0.031)\end{array}$ & $\begin{array}{c}-1.686 * * * \\
(0.132)\end{array}$ & $\begin{array}{l}-0.260 \\
(0.264)\end{array}$ & $\begin{array}{c}-1.581 * * * \\
(0.126)\end{array}$ \\
\hline CEO Tenure & $\begin{array}{c}0.025 * * * \\
(0.003)\end{array}$ & $\begin{array}{c}0.026 * * * \\
(0.002)\end{array}$ & $\begin{array}{c}0.005 \\
(0.007)\end{array}$ & $\begin{array}{c}0.145^{* * * *} \\
(0.014)\end{array}$ & $\begin{array}{c}0.106^{* * * *} \\
(0.007)\end{array}$ \\
\hline Institutional ownership & $\begin{array}{l}-0.039 \\
(0.032)\end{array}$ & $\begin{array}{c}-0.075 * * * \\
(0.020)\end{array}$ & $\begin{array}{c}0.245 * * * \\
(0.083)\end{array}$ & $\begin{array}{c}-2.971 * * * \\
(0.166)\end{array}$ & $\begin{array}{c}-0.807 * * * \\
(0.079)\end{array}$ \\
\hline G-index & $\begin{array}{l}-0.000 \\
(0.006)\end{array}$ & $\begin{array}{c}0.007 * * \\
(0.003)\end{array}$ & $\begin{array}{c}0.053 * * * \\
(0.014)\end{array}$ & $\begin{array}{c}0.149 * * * \\
(0.029)\end{array}$ & $\begin{array}{c}0.036 * * * \\
(0.014)\end{array}$ \\
\hline HHI & $\begin{array}{c}0.389 * * * \\
(0.086)\end{array}$ & $\begin{array}{c}0.329 * * * \\
(0.052)\end{array}$ & $\begin{array}{c}0.233 \\
(0.221)\end{array}$ & $\begin{array}{c}2.346 * * * \\
(0.442)\end{array}$ & $\begin{array}{c}-0.590 * * * \\
(0.211)\end{array}$ \\
\hline Year fixed effects & Yes & Yes & Yes & Yes & Yes \\
\hline Firm fixed effects & Yes & Yes & Yes & Yes & Yes \\
\hline$R^{2}$ & 0.14 & 0.14 & 0.06 & 0.08 & 0.10 \\
\hline Observations & 16,438 & 16,438 & 16,438 & 16,438 & 16,438 \\
\hline
\end{tabular}


B. CEO alignment, tariff cut, and corporate governance

\begin{tabular}{|c|c|c|c|c|c|c|c|c|}
\hline \multicolumn{9}{|l|}{ Dependent variable: Alignment } \\
\hline & \multicolumn{2}{|c|}{ G-index } & \multicolumn{2}{|c|}{ E-index } & \multicolumn{2}{|c|}{ Independence } & \multicolumn{2}{|c|}{ Institutional } \\
\hline & High & Low & High & Low & Low & High & Low & High \\
\hline & (1) & (2) & (3) & (4) & (5) & (6) & (7) & (8) \\
\hline \multirow[t]{2}{*}{ CUT_POST3 } & 0.058 & $0.221 * *$ & 0.124 & $0.469 * *$ & $0.114^{*}$ & $0.318^{* *}$ & 0.096 & $0.411 * * *$ \\
\hline & $(0.117)$ & $(0.095)$ & $(0.077)$ & $(0.166)$ & $(0.062)$ & $(0.112)$ & $(0.112)$ & $(0.075)$ \\
\hline Wald $\chi 2$ test for CUT_POST3 ( $p$-value) & & .04 & & .08 & & .09 & & .01 \\
\hline Other control variables & Yes & Yes & Yes & Yes & Yes & Yes & Yes & Yes \\
\hline Year fixed effects & Yes & Yes & Yes & Yes & Yes & Yes & Yes & Yes \\
\hline Firm fixed effects & Yes & Yes & Yes & Yes & Yes & Yes & Yes & Yes \\
\hline$R^{2}$ & 0.10 & 0.18 & 0.08 & 0.09 & 0.17 & 0.07 & 0.16 & 0.14 \\
\hline Observations & 9,793 & 6,645 & 11,179 & 5,259 & 3,856 & 7,418 & 8,698 & 7,740 \\
\hline
\end{tabular}

This table reports the results of panel regressions for firms without CEO turnovers for the first 3 years after a substantial tariff cut. CUT_POST3 is a dummy variable that equals 1 for the first 3 years after an industry has experienced a tariff rate reduction larger than 3 times the median tariff rate reduction in the same industry and 0 otherwise. Panel A examines the change of different components of CEO's compensation after tariff cut. Total_comp is natural logarithm of CEO's annual total compensation. Short_comp is natural logarithm of CEO's short-term compensation in the form of salary, bonus and other fixed annual payment. Long_comp is natural logarithm of CEO's long-term compensation in the form of stock and option grants and other long-term incentive payouts. Alignment is CEO's stock and option value sensitivities to a $\$ 100$ change in shareholder wealth. Pay_gap is natural logarithm of the difference between CEO's total compensation and the median of all other top 4 highest paid executives' total compensations. Panel B explores the change of CEO compensation alignment in firms with governance above and below the industry average. The governance measures are defined the same as in Table 5. All other control variables are the same as those in Column 3 in Table 2 and are defined in Table A1. Year and firm fixed effects are included in all columns. Robust standard errors, clustered by 3-digit SIC codes, are in parentheses. *, **, and $* * *$ indicate significance at the $10 \%, 5 \%$, and $1 \%$ level, respectively. 
Table 8

Tariff cuts and new CEO characteristics

\begin{tabular}{|c|c|c|c|c|c|c|}
\hline Variable & $\begin{array}{c}\text { COGS_PPENT } \\
(1) \\
\end{array}$ & $\begin{array}{c}\text { XSGA_PPENT } \\
\text { (2) }\end{array}$ & $\begin{array}{c}\text { SPPE_PPENT } \\
\text { (3) }\end{array}$ & $\begin{array}{c}\text { Prob(Asset_sale) } \\
(4)\end{array}$ & $\begin{array}{c}\text { Total_comp } \\
(5)\end{array}$ & $\begin{array}{c}\text { Alignment } \\
(6)\end{array}$ \\
\hline CUT & $\begin{array}{l}-0.644 * \\
(0.338)\end{array}$ & $\begin{array}{l}-0.419 \\
(0.381)\end{array}$ & $\begin{array}{l}0.008 * * \\
(0.003)\end{array}$ & $\begin{array}{l}0.418^{*} \\
(0.226)\end{array}$ & $\begin{array}{l}0.641 * \\
(0.358)\end{array}$ & $\begin{array}{l}0.452 * \\
(0.232)\end{array}$ \\
\hline IND_ADJ_ROA & $\begin{array}{l}-2.011 \\
(1.708)\end{array}$ & $\begin{array}{c}-2.496 * * \\
(1.086)\end{array}$ & $\begin{array}{c}-0.102 * * * \\
(0.016)\end{array}$ & $\begin{array}{c}0.437 \\
(1.343)\end{array}$ & $\begin{array}{c}0.655 \\
(0.810)\end{array}$ & $\begin{array}{l}0.959^{*} \\
(0.516)\end{array}$ \\
\hline IND_ADJ_RET & $\begin{array}{c}1.372 * * * \\
(0.331)\end{array}$ & $\begin{array}{c}0.152 \\
(0.200)\end{array}$ & $\begin{array}{l}-0.005 \\
(0.003)\end{array}$ & $\begin{array}{l}-0.057 \\
(0.215)\end{array}$ & $\begin{array}{c}0.003 \\
(0.159)\end{array}$ & $\begin{array}{l}-1.197 \\
(0.998)\end{array}$ \\
\hline Salechg & $\begin{array}{c}0.148 \\
(0.248)\end{array}$ & $\begin{array}{l}-0.184 \\
(0.278)\end{array}$ & $\begin{array}{c}0.014 * * * \\
(0.004)\end{array}$ & $\begin{array}{l}-0.604 \\
(0.474)\end{array}$ & $\begin{array}{l}-0.459 \\
(0.282)\end{array}$ & $\begin{array}{c}0.361 \\
(1.848)\end{array}$ \\
\hline Assets & $\begin{array}{l}-0.274 \\
(0.173)\end{array}$ & $\begin{array}{c}-0.476 * * * \\
(0.103)\end{array}$ & $\begin{array}{c}0.003 \\
(0.002)\end{array}$ & $\begin{array}{c}0.149 \\
(0.096)\end{array}$ & $\begin{array}{c}0.484 * * * \\
(0.087)\end{array}$ & $\begin{array}{l}-1.133 \\
(0.966)\end{array}$ \\
\hline$q$ & $\begin{array}{l}-0.188^{*} \\
(0.096)\end{array}$ & $\begin{array}{c}0.156 * * * \\
(0.058)\end{array}$ & $\begin{array}{c}0.012 * * * \\
(0.001)\end{array}$ & $\begin{array}{l}-0.023 \\
(0.085)\end{array}$ & $\begin{array}{c}0.058 \\
(0.037)\end{array}$ & $\begin{array}{c}0.166 * * * \\
(0.034)\end{array}$ \\
\hline CEO age & $\begin{array}{l}-0.004 \\
(0.025)\end{array}$ & $\begin{array}{l}-0.003 \\
(0.015)\end{array}$ & $\begin{array}{l}-0.000 \\
(0.000)\end{array}$ & $\begin{array}{l}-0.016 \\
(0.015)\end{array}$ & $\begin{array}{l}0.011 * * \\
(0.005)\end{array}$ & $\begin{array}{c}0.156 \\
(0.234)\end{array}$ \\
\hline Volatility & $\begin{array}{c}3.805 * * * \\
(1.051)\end{array}$ & $\begin{array}{c}2.567 * * * \\
(0.638)\end{array}$ & $\begin{array}{l}-0.016 \\
(0.011)\end{array}$ & $\begin{array}{l}-0.424 \\
(0.642)\end{array}$ & $\begin{array}{l}2.317 * * \\
(0.841)\end{array}$ & $\begin{array}{c}7.146 \\
(5.355)\end{array}$ \\
\hline Prior Total_comp & $\begin{array}{l}-0.158 \\
(0.236)\end{array}$ & $\begin{array}{l}0.308^{* *} \\
(0.139)\end{array}$ & $\begin{array}{c}-0.007 * * * \\
(0.002)\end{array}$ & $\begin{array}{l}-0.095 \\
(0.137)\end{array}$ & $\begin{array}{l}0.324 * * \\
(0.151)\end{array}$ & $\begin{array}{l}-0.489 \\
(1.095)\end{array}$ \\
\hline External & & & & & $\begin{array}{l}0.490 * * \\
(0.206)\end{array}$ & $\begin{array}{l}1.312 * * \\
(0.573)\end{array}$ \\
\hline$R^{2}$ & 0.13 & 0.19 & 0.43 & 0.26 & 0.48 & 0.36 \\
\hline Observations & 96 & 96 & 96 & 96 & 260 & 260 \\
\hline
\end{tabular}

This table reports the characteristics of new CEOs of firms that fire the incumbent CEOs. CUT is a dummy variable that equals 1 if an industry in which the firm operates has experienced a tariff rate reduction larger than 3 times the median tariff rate reduction in the same industry in any of the 3 years prior to new CEO's arrival and 0 otherwise. COGS_PPENT is cost of goods sold scaled by the total of property, plant, and equipment. XSGA_PPENT is selling, general, and administrative expenses scaled by the total of property, plant, and equipment. SPPE_PPENT is selling of property, plant, and equipment scaled by the total of property, plant, and equipment. COGS_PPENT, XSGA_PPENT, and SPPE_PPENT are averaged over the last 3 years in new CEO's old firm. Prob(Asset_sale) is a dummy variable that equals to $q$ if new CEO has made any subsidiary sales in the last 3 years in her old firm, and 0 otherwise. Total_comp is natural logarithm of new CEO's annual total compensation during the first full year in office. Alignment is new CEO's stock and option value sensitivities to a $\$ 100$ change in shareholder wealth during the first full year in office. External is a dummy variable equal to $q$ if the new CEO is an external hire, and 0 otherwise. Prior total_comp is new CEO's total compensation during the last year in her old firm. The first four columns only include new CEOs who are external hires. Table A1 defines all other variables. *, **, and $* * *$ indicate significance at the $10 \%, 5 \%$, and $1 \%$ level, respectively. 


\section{Table 9}

\section{Compensation structure of departing CEOs and new CEOs}

\begin{tabular}{|c|c|c|c|c|}
\hline & \multicolumn{2}{|r|}{ Departing CEO } & New CEO & Difference-in-means \\
\hline Total_comp & \multicolumn{2}{|r|}{7.087} & 7.385 & 0.299 \\
\hline Short_comp & \multicolumn{2}{|r|}{4.336} & 4.483 & 0.146 \\
\hline Long_comp & \multicolumn{2}{|r|}{6.142} & 6.822 & $0.679 * * *$ \\
\hline Alignment & \multicolumn{2}{|r|}{0.013} & 0.022 & $0.009 * * *$ \\
\hline Pay_gap & \multicolumn{2}{|r|}{5.899} & 6.611 & $0.712 * * *$ \\
\hline \multicolumn{5}{|c|}{ B. Difference-in-differences } \\
\hline & \multicolumn{2}{|c|}{ Average treated difference } & control difference & Difference-in-differences \\
\hline Total_comp & 0.299 & & 0.154 & $0.145^{* *}$ \\
\hline Short_comp & 0.14 & & 0.059 & 0.087 \\
\hline Long_comp & 0.679 & & 0.464 & $0.215^{*}$ \\
\hline Alignment & 0.00 & & 0.003 & $0.006 * *$ \\
\hline Pay_gap & 0.712 & & 0.137 & $0.575^{* *}$ \\
\hline
\end{tabular}

This table compares different aspects of compensation structure between departing CEOs and new CEOs. The treated firms are those that have CEO forced turnovers in any of the 3 years after a substantial tariff reduction. The control firms are those that have CEO forced turnover but there is no substantial tariff reduction in any of the 3 years prior to turnover. Total_comp is natural logarithm of CEO's annual total compensation. Short_comp is natural logarithm of CEO's short-term compensation in the form of salary, bonus and other fixed annual payment. Long_comp is natural logarithm of CEO's long-term compensation in the form of stock and option grants and other long-term incentive payouts. Alignment is CEO's stock and option value sensitivities to a $\$ 100$ change in shareholder wealth. Pay_gap is natural logarithm of the difference between CEO's total compensation and the median of all other highest paid executives' total compensations. Panel A presents the univariate analysis. For each forced turnover, we compute the mean of last full year's compensation of departing CEOs (Column 1), the mean of first full year's compensation of new CEOs (Column 2) and the difference in means between the new CEO and the departing CEO (Column 3). Panel $\mathrm{B}$ presents the difference in difference statistics. We compute the change of compensation between the new CEOs and the departing CEOs for treated firms (average treated difference), control firms (average control difference), and the difference between treated and control firms (difference-in-differences). $* * *$, and $* * *$ indicate statistical significance at the $10 \%, 5 \%$, and $1 \%$ level, respectively. 
Table 10

The effect of CEO turnover on corporate performance after tariff reduction

\begin{tabular}{|c|c|c|c|c|c|c|c|}
\hline & & $\begin{array}{c}\text { 1-year } \\
\text { average } \\
\text { difference }\end{array}$ & $\begin{array}{c}\text { Difference- } \\
\text { in- } \\
\text { differences }\end{array}$ & $\begin{array}{c}\text { 2-year } \\
\text { average } \\
\text { difference }\end{array}$ & $\begin{array}{c}\text { Difference- } \\
\text { in- } \\
\text { differences }\end{array}$ & $\begin{array}{c}\text { 3-year } \\
\text { average } \\
\text { difference }\end{array}$ & $\begin{array}{c}\text { Difference- } \\
\text { in- } \\
\text { differences }\end{array}$ \\
\hline \multirow[t]{2}{*}{ Profit margin } & Treated & 0.009 & $0.088^{* *}$ & 0.019 & $0.085^{* *}$ & 0.022 & $0.077 * *$ \\
\hline & Matched & -0.079 & & -0.066 & & -0.055 & \\
\hline \multirow[t]{2}{*}{ ROE } & Treated & 0.006 & 0.022 & 0.150 & $0.245^{* *}$ & 0.117 & $0.220^{* *}$ \\
\hline & Matched & -0.016 & & -0.095 & & -0.103 & \\
\hline \multirow[t]{2}{*}{ Sales growth } & Treated & -0.023 & 0.218 & 0.013 & $0.238 *$ & 0.014 & $0.297 * *$ \\
\hline & Matched & -0.241 & & -0.225 & & -0.283 & \\
\hline \multirow[t]{2}{*}{$q$} & Treated & -0.296 & 0.418 & -0.219 & 0.382 & -0.128 & 0.341 \\
\hline & Matched & -0.714 & & -0.601 & & -0.469 & \\
\hline \multirow[t]{2}{*}{ TFP } & Treated & 0.007 & $0.108^{* *}$ & 0.018 & $0.113^{* *}$ & 0.027 & $0.114 * *$ \\
\hline & Matched & -0.101 & & -0.095 & & -0.087 & \\
\hline
\end{tabular}

This table presents the difference-in-differences estimates for performance variables. The treated firms are those that have forced turnovers in any of the 3 years after a substantial tariff reduction. The firms are matched in the year of the turnover by the logarithm of total assets, the 3-digit SIC code, and the implied probability of CEO departure based on the model specification in Column 1 of Table 2. Profit margin is operating income before depreciation divided by sales. $R O E$ is net income divided by shareholder equity. Sales growth is the change of annual sales. $q$ is the Tobin's q. TFP is total factor productivity. For each performance variable, we compute the mean change from 1, 2, and 3 years before the turnover to 1,2, and 3 years after the turnover, respectively, for treated firms (average treated difference) and matched firms (average matched difference), and the difference between treated and matched firms (differencein-differences). $* * *$, and $* * *$ indicate statistical significance at the $10 \%, 5 \%$, and $1 \%$ level, respectively. 
Table 11

The effect of CEO turnover on corporate performance (tariff cut events versus normal times)

\begin{tabular}{|c|c|c|c|c|c|c|}
\hline & & \multicolumn{2}{|c|}{ Affected Firms } & \multicolumn{2}{|c|}{ Unaffected Firms } & \multirow[b]{2}{*}{$\begin{array}{c}\text { Triple } \\
\text { difference }\end{array}$} \\
\hline & & $\begin{array}{l}\text { 3-year average } \\
\text { difference }\end{array}$ & $\begin{array}{c}\text { Difference-in- } \\
\text { differences }\end{array}$ & $\begin{array}{l}\text { 3-year average } \\
\text { difference }\end{array}$ & $\begin{array}{c}\text { Difference-in- } \\
\text { differences }\end{array}$ & \\
\hline \multirow[t]{2}{*}{ Profit margin } & Treated & 0.022 & $0.077^{* *}$ & 0.011 & $0.049^{*}$ & 0.028 \\
\hline & Matched & -0.055 & & -0.038 & & \\
\hline \multirow[t]{2}{*}{ ROE } & Treated & 0.117 & $0.220 * *$ & -0.099 & $0.109 * *$ & $0.111^{*}$ \\
\hline & Matched & -0.103 & & -0.209 & & \\
\hline \multirow[t]{2}{*}{ Sales growth } & Treated & 0.014 & $0.297 * *$ & -0.081 & $0.149 * *$ & $0.148 * *$ \\
\hline & Matched & -0.283 & & -0.231 & & \\
\hline \multirow[t]{2}{*}{$q$} & Treated & -0.128 & 0.341 & -0.156 & 0.289 & 0.052 \\
\hline & Matched & -0.469 & & -0.445 & & \\
\hline \multirow[t]{2}{*}{ TFP } & Treated & 0.027 & $0.114^{* *}$ & -0.038 & -0.007 & $0.121 * *$ \\
\hline & Matched & -0.087 & & -0.031 & & \\
\hline
\end{tabular}

This table presents the triple-difference (difference-in-difference-in-difference) estimates for performance variables. The treated firms in the affected industries are those that have forced turnovers in any of the 3 years after substantial tariff reduction. For each treated firm in the affected industries, we randomly select another firm in the same industry that has a forced turnover occurring outside the 3-year window around a substantial tariff reduction event (control firms). The treated and control firms are matched in the year of the turnover by the logarithm of total assets, the 3digit SIC code, and the implied probability of CEO departure based on the model specification in Column 1 of Table 2 to firms in their respective industries (matched firms). We use four performance measures. Profit margin is operating income before depreciation divided by sales. $R O E$ is net income divided by shareholder equity. Sales growth is the change of annual sales. $q$ is the Tobin's q. TFP is total factor productivity. For each performance variable, we compute the mean change 3 years before the turnover to 3 years after the turnover for treated firms (average treated difference), control firms (average control difference) firms, and their respective matched firms (average matched difference). The difference-in-differences estimate is the difference between average treated (control) difference and their respective average matched difference. Triple difference is calculated based on the difference in difference-in-differences between treated and control firms. *,*, and *** indicate statistical significance at the $10 \%, 5 \%$, and $1 \%$ level, respectively. 
Table 12

The effect of CEO turnover on corporate performance after tariff reduction (subsample analysis)

\begin{tabular}{|c|c|c|c|c|c|c|c|}
\hline & & \multicolumn{2}{|c|}{ Deep pocket } & \multicolumn{2}{|c|}{ Financial flexibility } & \multicolumn{2}{|c|}{ Similarity } \\
\hline & & $\begin{array}{c}\text { Difference- } \\
\text { in- } \\
\text { differences }\end{array}$ & $\begin{array}{c}\text { Triple } \\
\text { difference }\end{array}$ & $\begin{array}{c}\text { Difference- } \\
\text { in- } \\
\text { differences }\end{array}$ & $\begin{array}{c}\text { Triple } \\
\text { difference }\end{array}$ & $\begin{array}{c}\text { Difference- } \\
\text { in- } \\
\text { differences }\end{array}$ & $\begin{array}{c}\text { Triple } \\
\text { difference }\end{array}$ \\
\hline \multirow[t]{2}{*}{ Profit margin } & High & 0.132 & $0.095^{* *}$ & 0.113 & $0.074 *$ & 0.141 & $0.074 *$ \\
\hline & Low & 0.037 & & 0.039 & & 0.067 & \\
\hline \multirow[t]{2}{*}{ ROE } & High & 0.292 & $0.217^{* *}$ & 0.242 & $0.153^{*}$ & 0.317 & $0.192 * *$ \\
\hline & Low & 0.075 & & 0.089 & & 0.151 & \\
\hline \multirow[t]{2}{*}{ Sales growth } & High & 0.338 & 0.101 & 0.379 & $0.232 *$ & 0.369 & $0.182 *$ \\
\hline & Low & 0.237 & & 0.147 & & 0.187 & \\
\hline \multirow[t]{2}{*}{$q$} & High & 0.312 & -0.037 & 0.360 & 0.063 & 0.343 & 0.064 \\
\hline & Low & 0.349 & & 0.297 & & 0.279 & \\
\hline \multirow[t]{2}{*}{ TFP } & High & 0.156 & $0.088^{*}$ & 0.163 & $0.076^{*}$ & 0.144 & $0.063 *$ \\
\hline & Low & 0.068 & & 0.087 & & 0.081 & \\
\hline
\end{tabular}

This table presents the triple difference (difference-in-difference-in-differences) estimates for performance variables. The treated firms are those that have forced turnovers in any of the 3 years after a substantial tariff reduction. The firms are matched in the year of the turnover by the logarithm of total assets, the 3-digit SIC code, and the implied probability of CEO departure based on the model specification in Column 1 of Table 2. We divide the treated firms into High and Low groups based on whether the industry in which the firm operates has Deep pocket, Financial flexibility or Similarity above or below the sample average in the year before the turnover. Deep pocket is the percentage of industry sales contributed by firms below the 25 th percentile of the industry leverage ratio. Financial flexibility is the percentage of industry sales contributed by firms above the 75th percentile of the industry cash to assets ratio. Similarity is the firm-level total similarity index based on Hoberg and Phillips (2011) and on the comparison of product descriptions in firms' $10-\mathrm{K}$ annual filings with the cosine similarity method. We use four performance measures. Profit margin is operating income before depreciation divided by sales. ROE is net income divided by shareholder equity. Sales growth is the change of annual sales. $q$ is the Tobin's q. TFP is total factor productivity. For each performance variable, we compute the mean change 3-year before the turnover to 3-year after the turnover for treated firms and matched firms, respectively. The difference between treated and matched firms (difference-in-differences) is reported for both High and Low groups. Triple difference is calculated based on the difference in difference-in-differences between High and Low groups. *, **, and *** indicate statistical significance at the $10 \%, 5 \%$, and $1 \%$ level, respectively. 


\section{APPENDIX}

\section{Table A1. Variable definitions}

\begin{tabular}{ll}
\hline Variable & \multicolumn{1}{c}{ Definition } \\
\hline IND_ADJ_ROA & Return on assets subtracted by average return on assets of all firms with the same \\
3-digit SIC code in the year prior to tariff cuts & Stock return subtracted by average stock return of all firms with the same 3-digit \\
IND_ADJ_RET & SIC code in the year prior to tariff cuts \\
Chalechg & Logange of firm sales from year $t$-1 to year $t$ \\
Assets & Tobin's q in year $t$ \\
$q$ & CEO's age in year $t$ \\
Age & Equals to 1 if the age of CEO in year $t$ is over 65, and 0 otherwise \\
Age_dummy & Standard deviation of firm monthly stock return from year $t$-5 to year $t$-1 \\
Volatility & The number of years as the firm's CEO in year $t$ \\
CEO tenure & The sum of ownership of all institutional investors who hold the firm stock in year $t$ \\
Institutional ownership & The governance index in year $t$ based on Gompers, Ishii, and Metrick (2003) \\
G-index & The industry Herfindahl-Hirschman index of firm sales in year $t$ \\
HHI & The number of directors in year $t$ \\
Board size & The proportion of independent directors on the board in year $t$ \\
Board independence &
\end{tabular}


Table A2

Tariff cuts and CEO forced turnover: PSM sample

\begin{tabular}{lccc}
\hline Variable & $(1)$ & $(2)$ & $(3)$ \\
\hline CUT_POST3 & & $0.026^{* *}$ & $0.021^{* *}$ \\
& & $(0.013)$ & $(0.010)$ \\
CUT_POST3 * IND_ADJ_ROA & & & $-0.009^{* *}$ \\
& & & $(0.004)$ \\
CUT_POST3 * IND_ADJ_RET & & & $-0.012^{* *}$ \\
& & & $(0.013)$ \\
IND_ADJ_ROA & $-0.037^{* *}$ & $-0.046^{*}$ & $-0.058^{*}$ \\
& $(0.016)$ & $(0.027)$ & $(0.028)$ \\
IND_ADJ_RET & $-0.071^{* * *}$ & $-0.069^{* * *}$ & $-0.058^{* * *}$ \\
& $(0.007)$ & $(0.007)$ & $(0.008)$ \\
Other control variables & & & Yes \\
Year fixed effects & Yes & Yes & Yes \\
Firm fixed effects & Yes & Yes & Yes \\
$R^{2}$ & 0.16 & 0.17 & 0.17 \\
Observations & 2,628 & 2,628 & 2,628 \\
\hline
\end{tabular}

This table reports the results of linear probability regression in which the dependent variable equals 1 if the CEO is forced to leave the firm in year $t$, and 0 otherwise. CUT_POST3 is a dummy variable that equals 1 for the first 3 years after an industry has experienced a tariff rate reduction larger than 3 times the median tariff rate reduction in the same industry, and 0 otherwise. The sample comprises treated firms that operate in industries that experience a significant import tariff reduction. In the year before the tariff cut, firms are matched by the logarithm of total assets, Tobin's q, cash flow to total assets, cash holding to total assets, and sales growth to firms in a different industry without significant tariff reduction. We keep treated and matched firms from 3 years before and 3 years after the tariff cut (excluding the event year). All other control variables are the same as those in Columns 3 and 5 in Table 2 and are defined in Table A1. Year and firm fixed effects are included in all columns. Robust standard errors, clustered by 3-digit standard industrial classification (SIC) codes, are in parentheses. *, **, and *** indicate significance at the $10 \%, 5 \%$, and $1 \%$ level, respectively. 
Table A3

Subperiod analysis

A. Turnover

\begin{tabular}{|c|c|c|c|c|}
\hline Variable & $\begin{array}{c}\text { Pre-WTO } \\
\text { (1) }\end{array}$ & $\begin{array}{c}\text { Post-WTO } \\
\text { (2) }\end{array}$ & $\begin{array}{c}\text { Clustering, low } \\
\text { (3) }\end{array}$ & $\begin{array}{c}\text { Clustering, high } \\
\text { (4) }\end{array}$ \\
\hline CUT_POST3 & $\begin{array}{c}0.017 \\
(0.013)\end{array}$ & $\begin{array}{c}0.032 * * * \\
(0.007)\end{array}$ & $\begin{array}{l}0.027 * \\
(0.014)\end{array}$ & $\begin{array}{c}0.046 * * * \\
(0.013)\end{array}$ \\
\hline Wald $\chi^{2}$ test for CUT_POST3 ( $p$-value) & & .03 & & .09 \\
\hline Other control variables & Yes & Yes & Yes & Yes \\
\hline Year fixed effects & Yes & Yes & Yes & Yes \\
\hline Firm fixed effects & Yes & Yes & Yes & Yes \\
\hline$R^{2}$ & 0.17 & 0.13 & 0.11 & 0.16 \\
\hline Observations & 4,233 & 16,315 & 13,457 & 7,091 \\
\hline \multicolumn{5}{|l|}{ B. Turnover-performance sensitivity } \\
\hline Variable & $\begin{array}{c}\text { Pre-WTO } \\
(1) \\
\end{array}$ & $\begin{array}{c}\text { Post-WTO } \\
(2) \\
\end{array}$ & $\begin{array}{c}\text { Clustering, low } \\
\text { (3) } \\
\end{array}$ & $\begin{array}{c}\text { Clustering, high } \\
\text { (4) } \\
\end{array}$ \\
\hline CUT_POST3 & $\begin{array}{c}0.018 \\
(0.013)\end{array}$ & $\begin{array}{c}0.030 * * * \\
(0.007)\end{array}$ & $\begin{array}{c}0.021 \\
(0.017)\end{array}$ & $\begin{array}{c}0.047 * * * \\
(0.013)\end{array}$ \\
\hline CUT_POST3 $*$ IND_ADJ_ROA & $\begin{array}{l}-0.027 \\
(0.022)\end{array}$ & $\begin{array}{c}-0.019 * * \\
(0.009)\end{array}$ & $\begin{array}{c}0.037 \\
(0.047)\end{array}$ & $\begin{array}{c}-0.018 * * \\
(0.008)\end{array}$ \\
\hline CUT_POST3 $*$ IND_ADJ_RET & $\begin{array}{c}0.002 \\
(0.007)\end{array}$ & $\begin{array}{c}-0.014 * * \\
(0.006)\end{array}$ & $\begin{array}{l}-0.006 \\
(0.009)\end{array}$ & $\begin{array}{c}-0.017 * * * \\
(0.003)\end{array}$ \\
\hline IND_ADJ_ROA & $\begin{array}{c}0.339 * * * \\
(0.119)\end{array}$ & $\begin{array}{c}-0.073 * * * \\
(0.021)\end{array}$ & $\begin{array}{c}-0.166 * * * \\
(0.028)\end{array}$ & $\begin{array}{c}0.092 * * * \\
(0.029)\end{array}$ \\
\hline IND_ADJ_RET & $\begin{array}{c}0.100 * * * \\
(0.012)\end{array}$ & $\begin{array}{c}-0.061 * * * \\
(0.004)\end{array}$ & $\begin{array}{c}-0.061 * * * \\
(0.005)\end{array}$ & $\begin{array}{c}-0.021 * * * \\
(0.007)\end{array}$ \\
\hline $\begin{array}{l}\text { Wald } \chi 2 \text { test for CUT_POST3 } \\
* \text { IND_ADJ_ROA ( } p \text {-value) }\end{array}$ & & .08 & & .05 \\
\hline $\begin{array}{l}\text { Wald } \chi 2 \text { test for CUT_POST3 } \\
* \text { IND_ADJ_RET ( } p \text {-value) }\end{array}$ & & .01 & & .01 \\
\hline Other control variables & Yes & Yes & Yes & Yes \\
\hline Year fixed effects & Yes & Yes & Yes & Yes \\
\hline Firm fixed effects & Yes & Yes & Yes & Yes \\
\hline$R^{2}$ & 0.18 & 0.13 & 0.11 & 0.17 \\
\hline Observations & 4,233 & 16,315 & 13,457 & 7,091 \\
\hline
\end{tabular}

This table reports the results of linear probability regression in which the dependent variable equals 1 if the CEO is forced to leave the firm in year $t$, and 0 otherwise. CUT_POST3 is a dummy variable that equals 1 for the first 3 years after an industry has experienced a tariff rate reduction larger than 3 times the median tariff rate reduction in the same industry, and 0 otherwise. Columns 1 and 2 cover the sample period before and after establishment of the World Trade Organization (WTO). Columns 3 and 4 cover the sample period in which the number of industries that experience substantial tariff reduction (Clustering) is above (high) or below (low) the sample mean. All other control variables are the same as those in Columns 3 and 5 of Table 2 and are defined in Table A1. Year and firm fixed effects are included in all columns. Robust standard errors, clustered by 3-digit SIC codes, are in parentheses. *, **, and *** indicate significance at the $10 \%, 5 \%$, and $1 \%$ level, respectively. 
Table A4

Additional robustness analysis (large versus small tariff cuts and industry concentration measures)

\begin{tabular}{|c|c|c|c|c|c|}
\hline $\begin{array}{l}\text { 4. Turnover } \\
\text { Variable }\end{array}$ & $\begin{array}{c}\text { Smaller cut } \\
\text { (1) }\end{array}$ & $\begin{array}{c}\text { Larger cut } \\
\text { (2) }\end{array}$ & \multicolumn{2}{|c|}{$\begin{array}{c}\text { HHI, low } \\
\text { (3) }\end{array}$} & $\begin{array}{c}\text { HHI, high } \\
\text { (4) }\end{array}$ \\
\hline CUT_POST3 & $\begin{array}{c}0.014 \\
(0.012)\end{array}$ & $\begin{array}{c}0.031 * * \\
(0.015)\end{array}$ & \multicolumn{2}{|c|}{$\begin{array}{c}0.018 * * \\
(0.007)\end{array}$} & $\begin{array}{c}0.029 * * \\
(0.010)\end{array}$ \\
\hline Wald $\chi 2$ test for CUT_POST3 ( $p$-value) & \multicolumn{4}{|c|}{.08} & .15 \\
\hline Other control variables & Yes & Yes & \multicolumn{2}{|c|}{ Yes } & Yes \\
\hline Year fixed effects & Yes & Yes & \multicolumn{2}{|c|}{ Yes } & Yes \\
\hline Firm fixed effects & Yes & Yes & \multicolumn{2}{|c|}{ Yes } & Yes \\
\hline$R^{2}$ & 0.11 & 0.10 & \multicolumn{2}{|c|}{0.11} & 0.13 \\
\hline Observations & 9,320 & 11,228 & \multicolumn{2}{|c|}{10,704} & 9,844 \\
\hline \multicolumn{6}{|l|}{ B. Turnover-performance sensitivity } \\
\hline Variable & & $\begin{array}{c}\text { Smaller cut } \\
(1) \\
\end{array}$ & $\begin{array}{c}\text { Larger cut } \\
\text { (2) }\end{array}$ & $\begin{array}{c}\text { HHI, low } \\
(3)\end{array}$ & $\begin{array}{c}\text { HHI, high } \\
\text { (4) }\end{array}$ \\
\hline CUT_POST3 & & $\begin{array}{c}0.013 \\
(0.011)\end{array}$ & $\begin{array}{c}0.029 * * * \\
(0.005)\end{array}$ & $\begin{array}{c}0.017 * * \\
(0.008)\end{array}$ & $\begin{array}{c}0.020 * * \\
(0.010)\end{array}$ \\
\hline CUT_POST3 $*$ IND_ADJ_ROA & & $\begin{array}{c}0.009 \\
(0.012)\end{array}$ & $\begin{array}{c}-0.028 * * * \\
(0.007)\end{array}$ & $\begin{array}{l}-0.026 \\
(0.042)\end{array}$ & $\begin{array}{c}-0.088 * * \\
(0.029)\end{array}$ \\
\hline CUT_POST3 $*$ IND_ADJ_RET & & $\begin{array}{l}-0.017 \\
(0.018)\end{array}$ & $\begin{array}{c}-0.013 * * \\
(0.006)\end{array}$ & $\begin{array}{l}-0.014^{*} \\
(0.008)\end{array}$ & $\begin{array}{c}-0.027^{* *} \\
(0.010)\end{array}$ \\
\hline IND_ADJ_ROA & & $\begin{array}{c}-0.154 * * * \\
(0.021)\end{array}$ & $\begin{array}{c}-0.145^{* * *} \\
(0.020)\end{array}$ & $\begin{array}{c}-0.063 * * \\
(0.025)\end{array}$ & $\begin{array}{c}-0.317 * * * \\
(0.035)\end{array}$ \\
\hline IND_ADJ_RET & & $\begin{array}{c}-0.048 * * * \\
(0.004)\end{array}$ & $\begin{array}{c}-0.051^{* * *} \\
(0.004)\end{array}$ & $\begin{array}{c}-0.035 * * * \\
(0.005)\end{array}$ & $\begin{array}{c}-0.082 * * * \\
(0.006)\end{array}$ \\
\hline \multicolumn{3}{|c|}{ Wald $\chi 2$ test for CUT_POST3 $*$ IND_ADJ_ROA ( $p$-value) } & \multicolumn{2}{|l|}{.02} & .03 \\
\hline \multicolumn{3}{|c|}{ Wald $\chi 2$ test for CUT_POST $3 *$ IND_ADJ_RET ( $p$-value) } & \multicolumn{2}{|l|}{.07} & .12 \\
\hline Other control variables & & Yes & Yes & Yes & Yes \\
\hline Year fixed effects & & Yes & Yes & Yes & Yes \\
\hline Firm fixed effects & & Yes & Yes & Yes & Yes \\
\hline$R^{2}$ & & 0.11 & 0.11 & 0.11 & 0.13 \\
\hline Observations & & 9,320 & 11,228 & 10,704 & 9,844 \\
\hline
\end{tabular}

This table reports the results of linear probability regression in which the dependent variable equals 1 if the CEO is forced to leave the firm in year $t$, and 0 otherwise. CUT_POST3 is a dummy variable that equals 1 for the first 3 years after an industry has experienced a tariff rate reduction larger than 3 times the median tariff rate reduction in the same industry, and 0 otherwise. In Columns 1 and 2, we only include small (large) substantial tariff cuts with the absolute change of tariff rate below (above) the mean of all absolute changes of tariff rate when an industry has experienced a tariff rate reduction larger than 3 times the median tariff rate reduction in the same industry. In Columns 3 and 4, all firms are divided into two subgroups based on whether the HHI of the industry in which the firm operates in the year before is below (low) or above (high) the sample average. All other control variables are the same as those in Columns 3 and 5 of Table 2 and are defined in Table A1. Year and industry fixed effects are included in all columns. Robust 
standard errors, clustered by 3 -digit SIC codes, are in parentheses. *, **, and $* * *$ indicate significance at the $10 \%$, $5 \%$, and $1 \%$ level, respectively.

Downloaded from https://academic.oup.com/rfs/advance-article-abstract/doi/10.1093/rfs/hhx129/4708265 by Health Sciences Library System user

on 18 December 2017 


\section{Table A5}

\section{Other robustness checks}

A. Turnover

\begin{tabular}{|c|c|c|c|c|c|}
\hline \multirow[b]{2}{*}{ Variable } & \multicolumn{2}{|c|}{ Diversification } & \multicolumn{2}{|c|}{ Segment } & \multirow{2}{*}{$\begin{array}{l}\text { Exporting } \\
\text { firms only } \\
(5)\end{array}$} \\
\hline & $\begin{array}{l}\text { High } \\
(1)\end{array}$ & $\begin{array}{c}\text { Low } \\
(2)\end{array}$ & $\begin{array}{c}\text { Multiple } \\
\text { (3) }\end{array}$ & $\begin{array}{c}\text { Single } \\
(4)\end{array}$ & \\
\hline CUT_POST3 & $\begin{array}{c}0.008 \\
(0.007)\end{array}$ & $\begin{array}{c}0.029 * * * \\
(0.010)\end{array}$ & $\begin{array}{c}0.019 * * \\
(0.009)\end{array}$ & $\begin{array}{c}0.039 * * * \\
(0.006)\end{array}$ & $\begin{array}{c}0.007 \\
(0.009)\end{array}$ \\
\hline Wald $\chi 2$ test for CUT_POST3 ( $p$-value) & & .06 & & .08 & \\
\hline Control variables & Yes & Yes & Yes & Yes & Yes \\
\hline Year fixed effects & Yes & Yes & Yes & Yes & Yes \\
\hline Firm fixed effects & Yes & Yes & Yes & Yes & Yes \\
\hline$R^{2}$ & 0.11 & 0.13 & 0.11 & 0.13 & 0.11 \\
\hline Observations & 12,039 & 8,509 & 16,176 & 4,372 & 10,821 \\
\hline
\end{tabular}




\begin{tabular}{|c|c|c|c|c|c|}
\hline \multirow[b]{2}{*}{ Variable } & \multicolumn{2}{|c|}{ Diversification } & \multicolumn{2}{|c|}{ Segment } & \multirow{2}{*}{$\begin{array}{c}\text { Exporting } \\
\text { firms } \\
\\
(5)\end{array}$} \\
\hline & $\begin{array}{l}\text { High } \\
(1)\end{array}$ & $\begin{array}{c}\text { Low } \\
(2)\end{array}$ & $\begin{array}{c}\text { Multiple } \\
\text { (3) }\end{array}$ & $\begin{array}{c}\text { Single } \\
(4)\end{array}$ & \\
\hline CUT_POST3 & $\begin{array}{c}0.007 \\
(0.006)\end{array}$ & $\begin{array}{c}0.020 * * \\
(0.010)\end{array}$ & $\begin{array}{l}0.017 * \\
(0.009)\end{array}$ & $\begin{array}{c}0.032 * * \\
(0.015)\end{array}$ & $\begin{array}{c}0.005 \\
(0.007)\end{array}$ \\
\hline CUT_POST3 $*$ IND_ADJ_ROA & $\begin{array}{c}-0.021 \\
(0.042)\end{array}$ & $\begin{array}{c}-0.033 * * * \\
(0.009)\end{array}$ & $\begin{array}{c}-0.024 * * * \\
(0.008)\end{array}$ & $\begin{array}{c}-0.049 * * * \\
(0.016)\end{array}$ & $\begin{array}{c}-0.047 \\
(0.059)\end{array}$ \\
\hline CUT_POST3 $*$ IND_ADJ_RET & $\begin{array}{c}-0.014 * \\
(0.007)\end{array}$ & $\begin{array}{c}-0.032 * * * \\
(0.007)\end{array}$ & $\begin{array}{c}-0.015 * * \\
(0.007)\end{array}$ & $\begin{array}{c}-0.031 * * * \\
(0.006)\end{array}$ & $\begin{array}{c}-0.007 \\
(0.010)\end{array}$ \\
\hline IND_ADJ_ROA & $\begin{array}{c}-0.063 * * \\
(0.025)\end{array}$ & $\begin{array}{c}-0.137 * * * \\
(0.035)\end{array}$ & $\begin{array}{c}-0.108 * * * \\
(0.021)\end{array}$ & $\begin{array}{c}-0.095 * * * \\
(0.012)\end{array}$ & $\begin{array}{c}-0.075 * * * \\
(0.014)\end{array}$ \\
\hline IND_ADJ_RET & $\begin{array}{c}-0.035 * * * \\
(0.005)\end{array}$ & $\begin{array}{c}-0.082 * * * \\
(0.006)\end{array}$ & $\begin{array}{c}-0.063 * * * \\
(0.004)\end{array}$ & $\begin{array}{c}0.055^{* * *} * \\
(0.014)\end{array}$ & $\begin{array}{c}-0.084 * * * \\
(0.006)\end{array}$ \\
\hline Wald $\chi 2$ for CUT_POST3 $*$ IND_ADJ_ROA ( $p$-value) & & .01 & & .14 & \\
\hline Wald $\chi 2$ for CUT_POST3 $*$ IND_ADJ_RET ( $p$-value) & & .07 & & .06 & \\
\hline Other control variables & Yes & Yes & Yes & Yes & Yes \\
\hline Year fixed effects & Yes & Yes & Yes & Yes & Yes \\
\hline Firm fixed effects & Yes & Yes & Yes & Yes & Yes \\
\hline$R^{2}$ & 0.11 & 0.13 & 0.12 & 0.14 & 0.12 \\
\hline Observations & 12,039 & 8,509 & 16,176 & 4,372 & 10,821 \\
\hline
\end{tabular}

This table reports the results of linear probability regression in which the dependent variable equals 1 if the CEO is forced to leave the firm in year $t$, and 0 otherwise. CUT_POST3 is a dummy variable that equals 1 for the first 3 years after an industry has experienced a tariff rate reduction larger than 3 times the median tariff rate reduction in the same industry, and 0 otherwise. Columns 1 and 2 contain firms with high (low) Diversification, which is measured by the HHI of segment sales. High (low) corresponds to the HHI being below (above) the mean of all firms in the same industry (3-digit SIC code) in the year before. Columns 3 and 4 contain firms with multiple (single) segment. Column 5 has only firms with positive export sales. Year and firm fixed effects are included in all columns. All other control variables are the same as those in Columns 3 and 5 of Table 2 and are defined in Table A1. Robust standard errors, clustered by 3 -digit SIC codes, are in parentheses. $* * *$, and $* * *$ indicate significance at the $10 \%, 5 \%$, and $1 \%$ level, respectively. 
Table A6

Tariff cuts and CEO forced turnover (probit model)

\begin{tabular}{|c|c|c|c|c|c|c|c|c|}
\hline Variable & (1) & (2) & (3) & (4) & (5) & (6) & (7) & (8) \\
\hline & & & & & & & Placebo & Placebo \\
\hline CUT_POST3 & & $\begin{array}{c}0.124 * * * \\
(0.026)\end{array}$ & $\begin{array}{c}0.159 * * * \\
(0.038)\end{array}$ & $\begin{array}{c}0.184 * * \\
(0.069)\end{array}$ & $\begin{array}{c}0.137 * * * \\
(0.038)\end{array}$ & $\begin{array}{c}0.114 * * \\
(0.049)\end{array}$ & $\begin{array}{c}0.026 \\
(0.038)\end{array}$ & $\begin{array}{c}0.014 \\
(0.039)\end{array}$ \\
\hline CUT_POST3 $*$ ROA & & & & & $\begin{array}{c}-0.467 * * \\
(0.208)\end{array}$ & $\begin{array}{c}-0.326 * * \\
(0.148)\end{array}$ & & $\begin{array}{l}-0.146 \\
(0.288)\end{array}$ \\
\hline CUT_POST3 $*$ RET & & & & & $\begin{array}{c}-0.248 * * \\
(0.083)\end{array}$ & $\begin{array}{l}-0.213 * \\
(0.110)\end{array}$ & & $\begin{array}{c}0.106 \\
(0.112)\end{array}$ \\
\hline $\mathrm{ROA}$ & $\begin{array}{c}-0.307 * * * \\
(0.093)\end{array}$ & & $\begin{array}{c}-0.351 * * * \\
(0.108)\end{array}$ & $\begin{array}{c}-0.321 * * \\
(0.151)\end{array}$ & $\begin{array}{c}-0.256 * * \\
(0.125)\end{array}$ & $\begin{array}{c}-0.284 * * \\
(0.109)\end{array}$ & $\begin{array}{c}-0.351 * * * \\
(0.107)\end{array}$ & $\begin{array}{c}-0.291 * * \\
(0.113)\end{array}$ \\
\hline RET & $\begin{array}{c}-0.671 * * * \\
(0.035)\end{array}$ & & $\begin{array}{c}-0.695 * * * \\
(0.037)\end{array}$ & $\begin{array}{l}-0.608 * \\
(0.043)\end{array}$ & $\begin{array}{c}-0.482 * * * \\
(0.037)\end{array}$ & $\begin{array}{c}-0.568 * * * \\
(0.042)\end{array}$ & $\begin{array}{c}-0.693 * * * \\
(0.037)\end{array}$ & $\begin{array}{c}-0.682 * * * \\
(0.038)\end{array}$ \\
\hline Marginal effects for CUT_POST3 & & $0.013 * * *$ & $0.016 * * *$ & $0.020 * *$ & & & 0.003 & \\
\hline Marginal effects for CUT_POST3 $*$ ROA & & & & & $-0.037 * *$ & $-0.026 * *$ & & -0.012 \\
\hline Marginal effects for CUT_POST3 $*$ RET & & & & & $-0.021 * *$ & $-0.015^{*}$ & & 0.008 \\
\hline Control variables & Yes & No & Yes & Yes & Yes & Yes & Yes & Yes \\
\hline Year fixed effects & Yes & Yes & Yes & Yes & Yes & Yes & Yes & Yes \\
\hline Industry fixed effects & Yes & Yes & Yes & Yes & Yes & Yes & Yes & Yes \\
\hline Pseudo $R^{2}$ & 0.22 & 0.09 & 0.24 & 0.25 & 0.25 & 0.26 & 0.23 & 0.24 \\
\hline Observations & 20,548 & 20,548 & 20,548 & 14,093 & 20,548 & 14,093 & 20,548 & 20,548 \\
\hline
\end{tabular}

This table reports the results of a probit regression. The dependent variable equals 1 if the CEO is forced to leave the firm in year $t$, and 0 otherwise. $C U T \_P O S T 3$ is a dummy variable that equals 1 for the first 3 years after an industry has experienced a tariff rate reduction larger than 3 times the median tariff rate reduction in the same industry, and 0 otherwise. All other control variables are the same as those in Columns 3 and 5 in Table 2 and are defined in Table A1. Year and industry fixed effects are included in all columns. Columns 4 and 6 use board size and independence as additional control variables. In Columns 7 and 8 , we assign tariff cut events randomly to perform a placebo test. Robust standard errors, clustered by 3 -digit standard industrial classification (SIC) codes, are in parentheses. *, **, and $* * *$ indicate significance at the $10 \%, 5 \%$, and $1 \%$ level, respectively. 
(a)

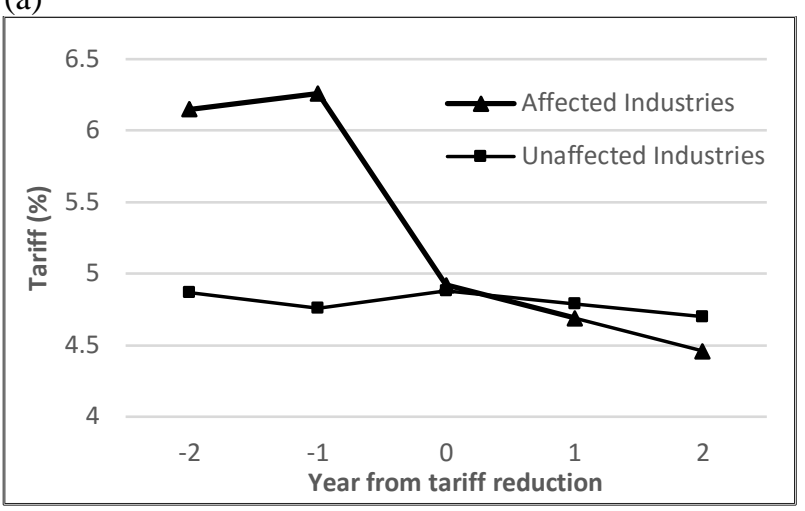

(b)

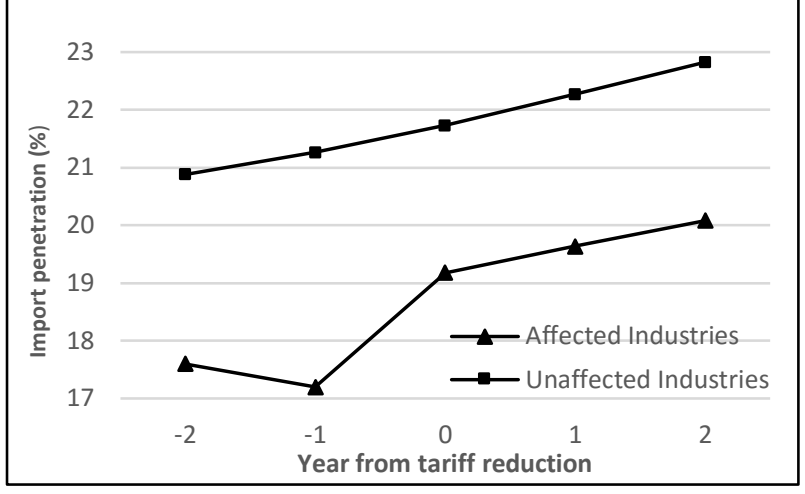

(c)

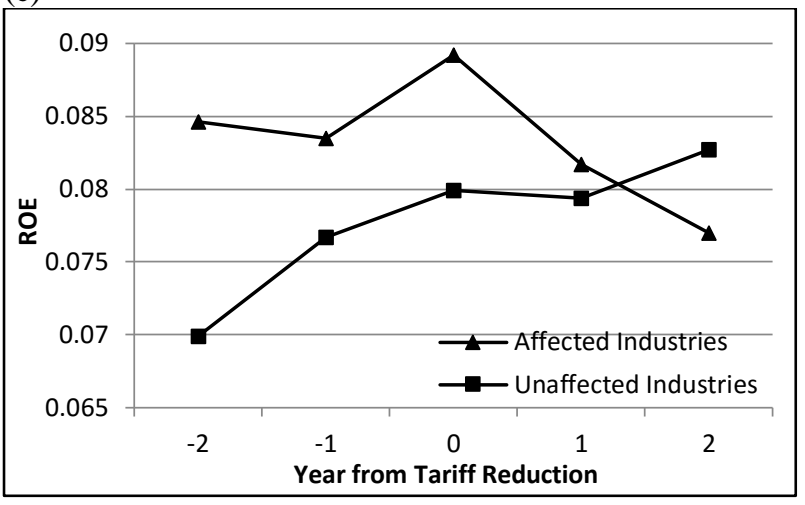

(d)

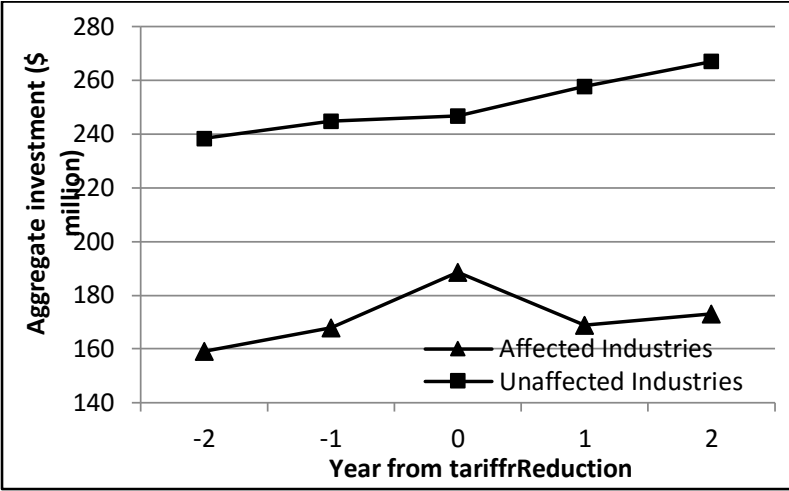

(e) 

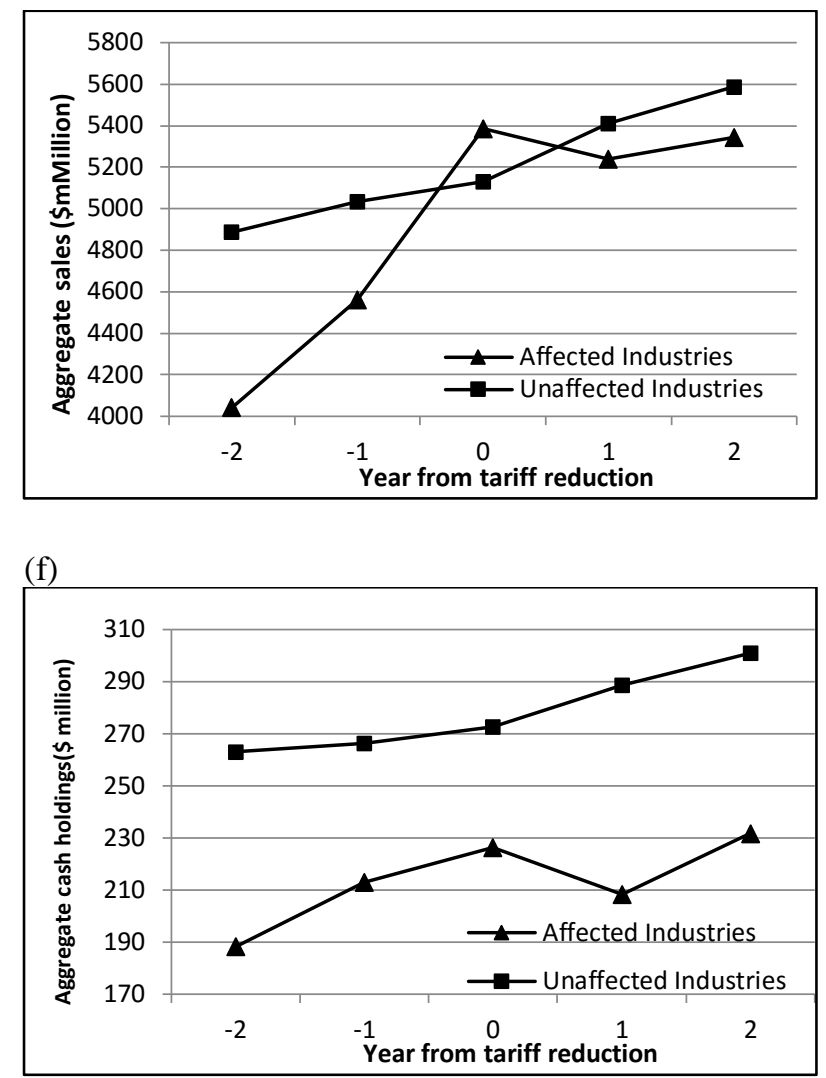

\section{Figure 1}

\section{Tariff rate and industry performance around tariff rate reduction}

The figure shows the tariff rate and industry performance in event time for the sample of affected and unaffected industries (based on 3-digit SIC). The sample consists of all industries that are matched to tariff data. Affected industries are those that experience a substantial tariff reduction in the event year. Unaffected industries are those that do not have a substantial tariff reduction in the 3 years before and after event year (including event year). Tariff rates are computed at the 3-digit SIC industry level as duties collected at U.S. Custom divided by the freeon-board customs value of imports. Import penetration is computed at the 3-digit SIC industry level as total imports divided by domestic production plus total imports minus total exports. Aggregate investment, sales and cash holdings are the summations of these variables over all firms in each industry. ROE is return on equity measured by net income divided by shareholder equity. The panels show the median value of each variable in event year for all affected and unaffected industries, respectively. 


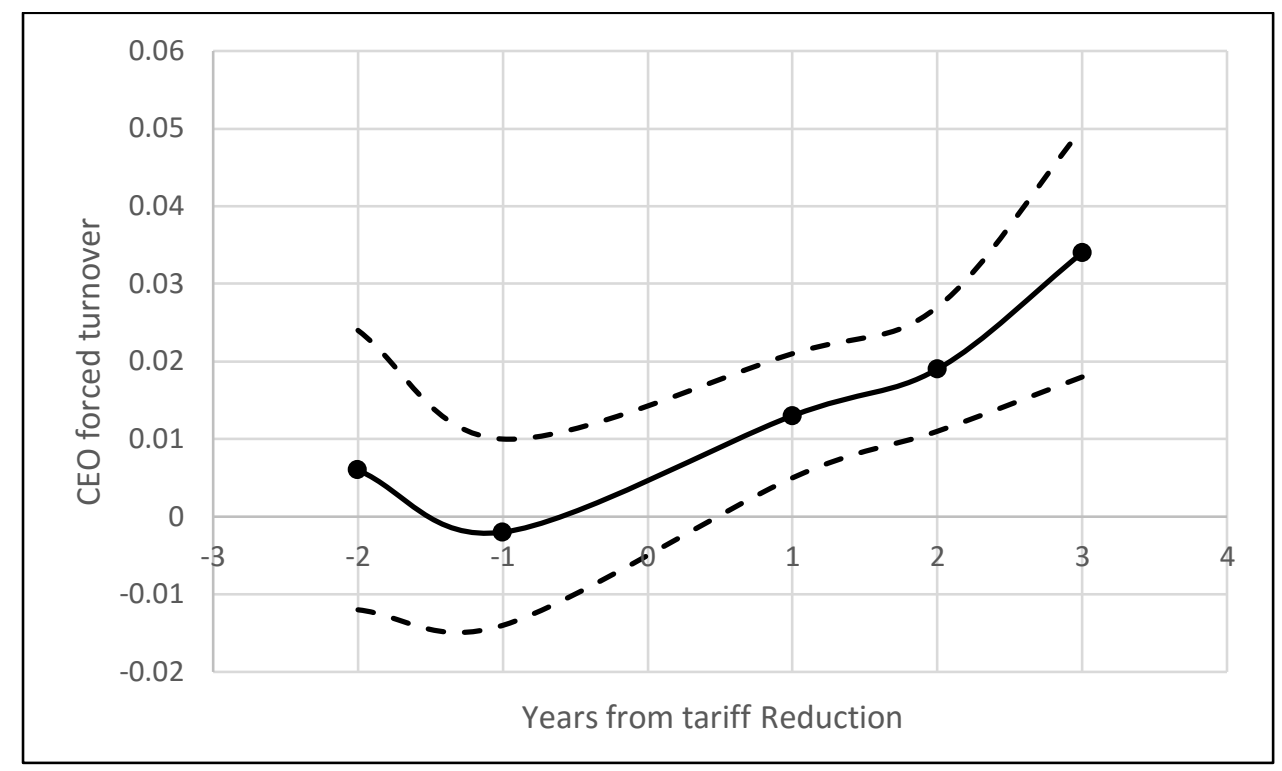

\section{Figure 2}

\section{Dynamic effect of tariff reduction on CEO forced turnover}

The figure reports the point estimates from a linear probability regression of CEO forced turnover on tariff cut. The specification is the same as that reported in Table 2, Column 3, except that the effect of tariff cut is allowed to vary by year for each year from 2 years before the tariff cut to 3 years after. Also plotted are $95 \%$ confidence intervals (dash lines), adjusted for clustering at the 3-digit standard industrial classification (SIC) codes. 


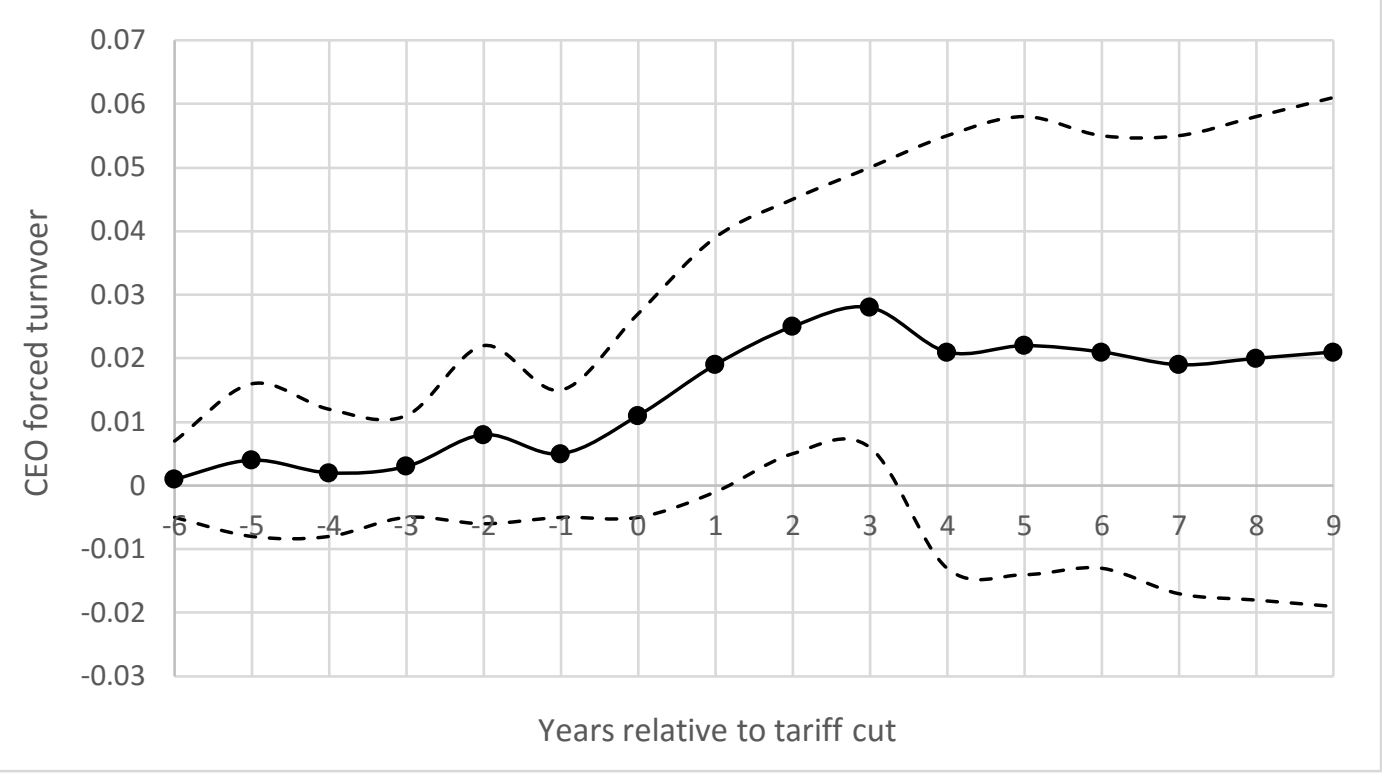

\section{Figure 3}

Dynamic effect of tariff reduction on CEO forced turnover (panel data)

The figure reports the point estimates from a linear probability regression of CEO forced turnover on tariff cut using firm-year panel data. The specification is the same as that reported in Table 2, Column 3, except that the effect of tariff cut is allowed to vary by year for each year from 6 years before the tariff cut to 9 years after. Also plotted are $95 \%$ confidence intervals (dash lines), adjusted for clustering at the 3-digit standard industrial classification (SIC) codes. 